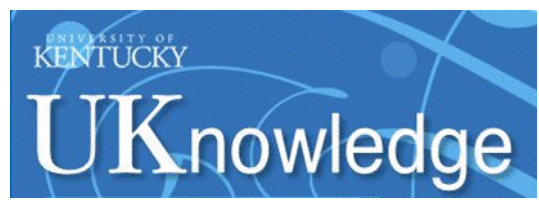

University of Kentucky

UKnowledge

\title{
Extended-Spectrum Antiprotozoal Bumped Kinase Inhibitors: A Review
}

\author{
Wesley C. Van Voorhis \\ University of Washington \\ J. Stone Doggett \\ Portland VA Medical Center \\ Marilyn Parsons \\ University of Washington \\ Matthew A. Hulverson \\ University of Washington \\ Ryan Choi \\ University of Washington
}

Sellowe this and addditionalworkşat: https://uknowledge.uky.edu/gluck_facpub

Part of the Animal Sciences Commons, Immunology of Infectious Disease Commons, and the Parasitology Commons

Right click to open a feedback form in a new tab to let us know how this document benefits you.

\section{Repository Citation}

Van Voorhis, Wesley C.; Doggett, J. Stone; Parsons, Marilyn; Hulverson, Matthew A.; Choi, Ryan; Arnold, Samuel L. M.; Riggs, Michael W.; Hemphill, Andrew; Howe, Daniel K.; Mealey, Robert H.; Lau, Audrey O. T.; Merritt, Ethan A.; Maly, Dustin J.; Fan, Erkang; and Ojo, Kayode K., "Extended-Spectrum Antiprotozoal Bumped Kinase Inhibitors: A Review" (2017). Veterinary Science Faculty Publications. 45.

https://uknowledge.uky.edu/gluck_facpub/45

This Article is brought to you for free and open access by the Veterinary Science at UKnowledge. It has been accepted for inclusion in Veterinary Science Faculty Publications by an authorized administrator of UKnowledge. For more information, please contact UKnowledge@lsv.uky.edu. 


\section{Extended-Spectrum Antiprotozoal Bumped Kinase Inhibitors: A Review}

\section{Digital Object Identifier (DOI)}

https://doi.org/10.1016/j.exppara.2017.01.001

\section{Notes/Citation Information}

Published in Experimental Parasitology, v. 180, p. 71-83.

(c) 2017 Elsevier Inc. All rights reserved.

This manuscript version is made available under the CC-BY-NC-ND 4.0 license

https://creativecommons.org/licenses/by-nc-nd/4.0/.

The document available for download is the author's post-peer-review final draft of the article.

\section{Authors}

Wesley C. Van Voorhis, J. Stone Doggett, Marilyn Parsons, Matthew A. Hulverson, Ryan Choi, Samuel L. M. Arnold, Michael W. Riggs, Andrew Hemphill, Daniel K. Howe, Robert H. Mealey, Audrey O. T. Lau, Ethan A. Merritt, Dustin J. Maly, Erkang Fan, and Kayode K. Ojo 


\title{
Extended-Spectrum Antiprotozoal Bumped Kinase Inhibitors: A Review
}

\author{
Wesley C. Van Voorhis ${ }^{a, b,{ }^{*}}$, J. Stone Doggett ${ }^{c}$, Marilyn Parsons $^{b, d}$, Matthew A. Hulverson ${ }^{a}$, \\ Ryan Choi ${ }^{\mathrm{a}}$, Samuel Arnold ${ }^{\mathrm{a}}$, Michael W. Riggs ${ }^{\mathrm{e}}$, Andrew Hemphill ${ }^{f}$, Daniel K. Howe ${ }^{\mathrm{g}}$, \\ Robert H. Mealey ${ }^{h}$, Audrey O. T. Lau', Ethan A. Merritt', Dustin J. Malyk, Erkang Fan', and \\ Kayode K. Ojo ${ }^{\mathrm{a},{ }^{*}}$
}

aDepartment of Medicine, Division of Allergy and Infectious Disease, Center for Emerging and Reemerging Infectious Disease (CERID), University of Washington, Seattle, WA 98109 USA ${ }^{b}$ Department of Global Health, University of Washington, Seattle, WA 98195 USA ${ }^{\text {cPortland VA }}$ Medical Center, Portland, OR 97239, United States ${ }^{d}$ Center for Infectious Disease Research, Seattle, WA 98109 USA eSchool of Animal and Comparative Biomedical Sciences, College of Agriculture and Life Sciences, University of Arizona, Tucson, Arizona 85721 USA f Institute of Parasitology, Vetsuisse Faculty, University of Berne, Berne, Switzerland gDepartment of Veterinary Science, University of Kentucky, Lexington, KY 40546 USA hDepartment of Veterinary Microbiology and Pathology, College of Veterinary Medicine, Washington State University, Pullman, WA 99164-7040 'The National Institutes of Health, NIAID, DEA, 5601 Fishers Lane, Rockville, MD 20892 USA iDepartment of Biochemistry, University of Washington, Seattle, WA 98195 USA kDepartment of Chemistry, University of Washington, Seattle, WA 98195 USA

\section{Abstract}

Many life-cycle processes in parasites are regulated by protein phosphorylation. Hence, disruption of essential protein kinase function has been explored for therapy of parasitic diseases. However, the difficulty of inhibiting parasite protein kinases to the exclusion of host orthologues poses a practical challenge. A possible path around this difficulty is the use of bumped kinase inhibitors for targeting calcium dependent protein kinases that contain atypically small gatekeeper residues and are crucial for pathogenic apicomplexan parasites' survival and proliferation. In this review, we review efficacy against the kinase target, the parasite growth in vitro, and in animal infection models, as well as the relevant pharmacokinetic and safety parameters of bumped-kinase inhibitors.

\section{Graphical abstract}

\footnotetext{
*Corresponding authors. Wesley C. Van Voorhis, Kayode K. Ojo, Division of Allergy and Infectious Disease, Center for Emerging and Reemerging Infectious Disease (CERID), University of Washington, 750 Republican Street, Box 358061, Seattle, WA 98109 USA. wesley@uw.edu (Wesley C. Van Voorhis), ojo67kk@u.washington.edu (Kayode K. Ojo).

Publisher's Disclaimer: This is a PDF file of an unedited manuscript that has been accepted for publication. As a service to our customers we are providing this early version of the manuscript. The manuscript will undergo copyediting, typesetting, and review of the resulting proof before it is published in its final citable form. Please note that during the production process errors may be discovered which could affect the content, and all legal disclaimers that apply to the journal pertain.
} 


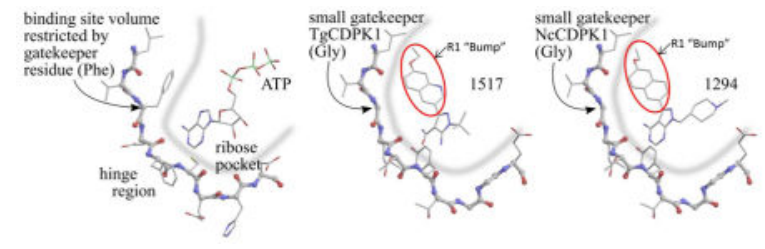

\section{Keywords}

Bumped-kinase inhibitors; Calcium-dependent protein kinase; Gatekeeper residue

\section{Introduction}

Protein kinase inhibitors have been sought for therapy of parasitic diseases, but the challenge of specific inhibition of parasite kinases versus mammalian kinases has limited their practical application. Bumped-kinase inhibitors (BKIs) were originally generated in Prof. Kevan Shokat's laboratory to build specificity into protein kinase inhibitors that compete with ATP for the kinase active site (Bishop, et al., 1998, Bishop and Shokat, 1999) The "bump" on BKIs precludes their binding to almost all mammalian kinases, since these have a bulky gatekeeper residue in the ATP-binding pocket (see Fig. 1, below). Dr. Shokat's group pioneered the use of BKIs in genetically-altered mammalian kinases, in which the bulky gatekeeper residue was mutated to glycine or alanine, rendering the mutant kinase susceptible to BKIs (Bishop, et al., 2000, Liu, et al., 1999) If the mutant protein kinase was active, the mutation could be introduced into the corresponding gene in mice, allowing the function of that kinase to be probed anytime during the life of the mice by inhibiting that kinase specifically with BKIs. BKIs had no discernable effects on wild-type mice in control experiments, providing evidence that these compounds as a class have low activity against mammalian kinases and hence low toxicity.

We and Dr. Hui's group determined the structure of Toxoplasma gondii and Cryptosporidium parvum calcium-dependent protein kinase 1 (CDPK1) and immediately noticed that these parasite proteins contain a naturally occurring glycine gatekeeper residue in the ATP binding site (Ojo, et al., 2010, Wernimont, et al., 2010). We reasoned that this active site should therefore be sensitive to BKI inhibition and found that to be the case experimentally. Given the safety and specificity of BKIs demonstrated by Shokat's group, we embarked on a medicinal chemistry project to optimize BKIs for use against parasites that have CDPKs, primarily apicomplexans. This review describes progress in this area.

\section{Structural Basis of Cross-Parasite CDPK inhibition by BKIs}

CDPKs have no closely related orthologs in vertebrates, but the CDPK kinase domain is similar in sequence and structure to other members of the large family of serine threonine kinases. As with many protein kinases, CDPKs have conformationally distinct active and inactive states that differ in their competence to bind to and act on their protein substrates. CDPK activity is not regulated through phosphorylation or interaction with a partner protein. Instead, regulation is accomplished via a radical reorganization of the calcium-binding 
domain such that in the Ca-bound active state, substrate proteins have unobstructed access to the face of the CDPK containing the active site, while in the inactive state, access to this face of the protein is occluded (Ojo, et al., 2010, Wernimont, et al., 2010). The internal conformation of the active site pocket is unchanged between the active and inactive state. Even the "inactive" state is catalytically competent to phosphorylate small peptide substrates, and crystal structures show that the binding pose of ATP, ATP analogs, and ATPcompetitive inhibitors is maintained in both conformations (Murphy, et al., 2010, Wernimont, et al., 2010). Thus, both the active and inactive states of CDPKs are targeted by the BKIs discussed here.

The overall ATP binding pocket comprises three areas necessarily shared by all kinases: a region adjacent to the ATP $\beta$ and 7gamma; phosphates containing the catalytic residues, a relatively hydrophilic pocket that accommodates the ATP ribose moiety, and a relatively hydrophobic pocket that accommodates the ATP purine group. Given this set of necessarily shared features, how is it possible to systematically design highly selective ATP-competitive compounds that potently inhibit target CDPKs in apicomplexan parasites while showing weak or no inhibition of mammalian kinases? The first key is a difference in the hydrophobic pocket that accommodates the ATP purine group. In a typical kinase the accessible volume of this pocket is limited by the side chain of a particular residue, the "gatekeeper" residue, whose position in the active site is strongly conserved (Zuccotto, et al., 2010). The surface of the binding site formed by this gatekeeper sidechain is near atom N7 of the ATP purine group and in a typical kinase prevents recognition of ATP analogs that have been chemically modified by the addition of a bulky group, colloquially called a "bump", at this position. Substitution of a small amino acid (i.e., glycine, alanine, or serine) at the gatekeeper position removes this restriction, resulting in an enlarged hydrophobic pocket that can accommodate ATP analogs with such a bump. As noted above, BKIs were originally developed to exploit engineered large to small gatekeeper substitutions to create highly specific biological probes of kinase function (Bishop, et al., 2001, Bishop, et al., 2000). Because small gatekeepers are universally rare in wild type mammalian kinases, pairing the introduction of an engineered sensitive kinase with a suitable bumped ATP analog or inhibitor constitutes a highly selective probe for that specific kinase (Zhang, et al., 2005).

Various CDPK family members in apicomplexan parasites naturally possess a small gatekeeper residue. CDPK1 homologs from Toxoplasma gondii, Cryptosporidium parvum, Neospora caninum, and Sarcocystis neurona contain a glycine gatekeeper. CDPK4 from Plasmodium falciparum contains a serine. Previously characterized BKIs such as the pyrazolopyrimidines (PP) (Liu, et al., 1999) presented an obvious starting point for optimization of inhibitors highly selective for the target parasite enzymes over most host kinases (Johnson, et al., 2012, Lourido, et al., 2013, Murphy, et al., 2010). Human kinases containing a threonine gatekeeper, the next smallest amino acid, were thought to account for the initially imperfect BKI selectivity. Crystallographic comparison of BKIs bound to CDPK1 and to the representative threonine gatekeeper human kinase SRC showed that it is possible to increase selectivity by exploiting differences among kinases in the relative orientation of the ribose binding pocket (Larson, et al., 2012). This led to an optimization strategy that explored simultaneous substitution at two positions in the starting PP scaffold. 
Substituents at the R1 position, the BKI "bump", strongly reduce acceptance of gatekeepers larger than threonine; substituents at the $\mathrm{R} 2$ position extend into the ribose pocket and further restrict acceptance by threonine gatekeeper kinases.

The geometric presentation of the R1 and R2 groups characterized for the original PP scaffold is preserved by analogous substitutions onto an alternative 5-aminopyrazole-4carboxamide (AC) scaffold (Huang, et al., 2015, Zhang, et al., 2014). Thus both scaffolds exploit the same two primary determinants of CDPK1-specific inhibition (Fig. 1). The pharmacological properties of compounds based the two scaffolds differ, however. Both scaffolds are represented in the set of compounds discussed below that have shown the most promise in animal tests. Two other BKI scaffolds (Fig. 2) that do not preserve this precise geometry of presenting substituents have also been explored to target apicomplexan CDPKs, imidazopyridazines to target PfCDPK1 (Chapman, et al., 2013, Chapman, et al., 2014, Green, et al., 2016), and benzoylbenzimidazoles to target $T g$ CDPK1 and $C p$ CDPK1 (Zhang, et al., 2012).

Joint optimization of the R1 and R2 substituents has led to inhibitors that are >200-fold more active in vitro against CDPKs than against a panel of 80 to 240 human kinases (Vidadala, et al., 2016, Zhang, et al., 2014). This selective difference in activity is sufficiently great to offer hope that further chemical elaboration, in particular of the R2 group, may allow distinguishing selectively between threonine-gatekeeper kinases of parasite and host. This extends the range of parasitic diseases potentially treatable with BKI drugs to include those caused by Plasmodium (Chapman, et al., 2013), Eimeria (Keyloun, et al., 2014), Theileria (Hines, et al., 2015), and Babesia (Pedroni, et al., 2016), all of which express threonine gatekeeper CDPKs. A validation of CDPK(s) as the sole molecular target(s) that cause inhibition of growth and proliferation of an apicomplexan parasite cells when exposed to BKIs will still need chemical genetic determination as demonstrated in $T$. gondii.

\section{Inhibition of Apicomplexan parasite growth and replication by BKIs}

\subsection{Toxoplasma}

Toxoplasma gondii is a protozoan parasite that is broadly distributed throughout the world infecting mammals and birds, providing a large reservoir for human infection (Tenter, et al., 2000). Human toxoplasmosis is most often asymptomatic or causes mild, self-limited symptoms, which includes the formation of tissue cysts that persist in the host brain and other organs indefinitely. However, severe infections may cause blindness, disability or death. Persons previously infected with $T$. gondii (and hence are still carrying parasite cysts) who have AIDS or who have undergone allogeneic stem cell transplantation are at the greatest risk of developing toxoplasmosis (Martino, et al., 2005). The primary disease manifestation in immunocompromised patients is encephalitis, although ocular, pulmonary and disseminated toxoplasmosis also occur (Rabaud, et al., 1994) . Healthy persons may develop uveitis, and relapsing uveitis may lead to retinal scarring and loss of vision. The incidence of ocular disease varies geographically and is noted to be exceptionally high in areas of Brazil, possibly due to the prevalence of genetically distinct strains that circulate in South America (Dubey, et al., 2012, Khan, et al., 2006). Toxoplasma encephalitis and 
relapsing ocular disease result from the reactivation of tissue cysts, which are not eliminated by currently used anti-Toxoplasma medicines. Congenital toxoplasmosis results when an initial primary infection of a pregnant woman spreads to the fetus, which may cause miscarriage or developmental defects in the brain and eyes. Other human to human transmission is restricted to transfusions or transplants, reducing the propensity for the spread of drug resistance.

First line therapy for toxoplasmosis, the combination of pyrimethamine and sulfadiazine, has a high rate of toxic side effects that can lead to discontinuation of treatment (Dannemann, et al., 1992, Katlama, et al., 1996, Porter and Sande, 1992). Therapy for Toxoplasma encephalitis begins with six weeks of treatment that is then continued until immune reconstitution. The duration of treatment for congenital infection is at least one year while ocular infection is four to six weeks and may be extended to prevent relapse (Harrell and Carvounis, 2014, McLeod, et al., 2006). Improved therapy for toxoplasmosis would be orally available for use in resource-poor settings, achieve high brain and eye concentrations to treat encephalitis and uveitis and would be active against both the acute replicating tachyzoite and latent bradyzoite stages within tissue cysts. Moreover, new drugs should also prioritize having fewer, milder side effects and being effective in pregnancy.

Inhibition of $T$. gondii calcium-dependent protein kinase 1 ( $T g C D P K 1)$ has proven to be effective in models of experimental toxoplasmosis. $T g C D P K 1$ regulates the calciumdependent pathway of $T$. gondii microneme secretion and is required for gliding motility, host cell invasion and host cell egress (Lourido, et al., 2010). BKIs have been shown to halt T. gondii proliferation by blocking host-cell invasion and egress (Lourido, et al., 2010, Murphy, et al., 2010, Ojo, et al., 2010). However, parasites overexpressing CDPK1 with its glycine gatekeeper replaced by methionine are resistant to multiple BKIs (Johnson, et al., 2012, Ojo, et al., 2010, Vidadala, et al., 2016). Interestingly, T. gondii mitogen-activated protein kinase like 1 (TgMAPKL1, which has a serine gatekeeper) has been described as a secondary target for the BKI 1NM-PP1, based on the finding that a mutation in its gatekeeper residue was associated with decreased susceptibility to 1NM-PP1 and similar BKIs (Sugi, et al., 2015). Polypharmacology is common with kinase inhibitors, so it will be important to evaluate each BKI for its target specificity.

BKI synthesis based on the PP scaffold has resulted in potent TgCDPK1 inhibitors (Johnson, et al., 2012, Larson, et al., 2012, Murphy, et al., 2010, Vidadala, et al., 2016). Lourido et al. (2013) described a series of PP analogs. In this series, compounds 11 and 24 were metabolically stable and had in vitro $\mathrm{EC}_{50} \mathrm{~s}$ of $250 \mathrm{nM}$ and $610 \mathrm{nM}$. These compounds increased 30 day survival in mice infected with the type II Pru-LUC strain and decreased brain cysts when administered intraperitoneally prior to infection at $5 \mathrm{mg} / \mathrm{kg}$ for 10 days (Lourido, et al., 2013). Larson et al reported that development of the PP scaffold by adding a 6-alkoxy-2-naphthyl group at the R1 position, and a 4-piperidinylmethylene group at the R2 position further increased selectivity (Doggett, et al., 2014, Larson, et al., 2012). These BKIs were $>15,000$ fold more active against $T g C D P K 1$ compared to the human kinases SRC and $\mathrm{ABL}$ (which are among the rare human kinases with threonine gatekeeper residues), with no inhibition of the human kinases at $20 \mu \mathrm{M}$. BKI-1294 (Fig. 3), which was synthesized with $\mathrm{N}$-methylation of the 4- piperidinyl-methylene substituent to improve metabolic stability, 
had an in vitro $\mathrm{EC}_{50}$ of $140 \mathrm{nM}$ and reduced acute T. gondii infection in mice by $93 \%$ when given orally (or per os, P.O.) at $30 \mathrm{mg} / \mathrm{kg}$ (Doggett, et al., 2014). Upon further testing, BKI-1294 was found to inhibit the human Ether-à-go-go-Related Gene (hERG) ion channel, preventing further advancement for human toxoplasmosis due to the risk of cardiotoxicity. Vidadala et al., 2016 investigated modifications of the PP scaffold that maintained efficacy and selectivity for $T g$ CDPK1 while eliminating hERG liability. Compound 32, also known as BKI-1553 (Fig. 3), in their series of BKIs had a $>10 \mu \mathrm{M} \mathrm{IC}_{50}$ against hERG, a $60 \mathrm{nM}$ in vitro $\mathrm{EC}_{50}$ against $T$. gondii. BKI-1553 eliminated peritoneal $T$. gondii infection when administered P.O. to mice at $20 \mathrm{mg} / \mathrm{kg}$ for 5 days. In the latent $T$. gondii infection model using the ME49 strain, $30 \mathrm{mg} / \mathrm{kg}$ of BKI-1553 reduced the number of brain tissue cysts by $89 \%$. Pharmacokinetic studies in non-infected mice demonstrated a brain to plasma concentration ratio of 0.33 (Vidadala, et al., 2016), indicating good penetration for treatment of brain cysts.

Development of the 5-aminopyrazole-4-carboxamide (AC) scaffold identified BKIs 1586 and 1643 as lead compounds (Fig. 3). BKI-1643 had an in vitro $\mathrm{EC}_{50}$ of $45 \mathrm{nM}$ against $T$. gondii, and in an acute in vivo model using the RH strain, BKI-1643 reduced infection in the peritoneum below the limits of detection when given P.O. at $20 \mathrm{mg} / \mathrm{kg}$ for 5 days (Huang, et al., 2015). BKIs 1586 and 1643 had a brain to plasma concentration ratio of 0.16 and 0.43 , respectively.

In addition to the PP and AC scaffolds, an in vitro screen of a library of compounds against $T$. gondii identified biphenylimidazoazines as inhibitors of $T$. gondii growth (Moine, et al., 2015). Subsequently, a series of 14 imidazo[1,2-b]pyridazines based on the biphenylimidazoazines were found to inhibit $T g \mathrm{CDPK} 1$ in enzymatic studies at $\mathrm{IC}_{50} \mathrm{~s}<1 \mu \mathrm{M}$ and 7 compounds were found to inhibit $T$. gondii at $\mathrm{EC}_{50} \mathrm{~s}<1 \mu \mathrm{M}$. Several compounds in this series were found to have $\mathrm{EC}_{50} \mathrm{~s}$ at or below $100 \mathrm{nM}$ against $T$. gondii with minimal host cell toxicity, but they could not be further advanced due to pharmacokinetic issues (Moine, et al., 2015). At this point in preclinical development, BKIs possess the desirable characteristics of a new drug for toxoplasmosis: oral bioavailability, brain tissue penetration, pharmacokinetics that allow for once daily dosing, efficacy against acute and latent stages of T. gondii and no evidence of host toxicity. Although studies to identify the best BKI are ongoing, several suitable candidates for advanced drug development have emerged. The spread of drug resistance resulting from drug exposure is very unlikely given the rarity of human-to-human transmission of $T$. gondii, however, the development of resistance in individuals during treatment should be investigated. Given the promising results that have come from the extensive preclinical evaluation of the BKI class of compounds, BKIs demonstrate great potential for expanding and improving therapy for toxoplasmosis.

\subsection{Neospora}

Neospora caninum is phylogenetically closely related to Toxoplasma gondii, but several biological features distinguish these two species, including elements of their life cycle, host range, pathogenicity and ultrastructure (Hemphill, et al., 2016). Canids, namely dogs, wolves, dingoes and coyotes, represent definitive hosts, and $N$. caninum is capable of infecting and proliferating within a wide range of intermediates hosts, including cattle, 
sheep, goats, and many more (Dubey and Dubey, 2003). Extensive proliferation can lead to cellular destruction, tissue damage and immunopathology, and thus disease within these hosts. Neospora infections in humans have never been demonstrated. The parasite owes its economic importance primarily to the fact that it causes abortion in cattle, and stillbirth and/or birth of weak calves, with estimated annual losses of around 1.3 billion US dollars in the 10 countries where data is available (Reichel, et al., 2013). Natural $N$. caninum infection in sheep and concomitant Neospora-induced abortion problems have also been reported (Gonzalez-Warleta, et al., 2014, Moreno, et al., 2012). In addition, N. caninum infection can result in birth of clinically healthy, but persistently infected calves, which in turn then vertically transmit the parasite to the next generation. A number of proposed control options have been modeled, such as testing and culling of seropositive animals, discontinued breeding with offspring from seropositive cows, and vaccination of susceptible and infected animals. However, despite enormous efforts, vaccination against neosporosis has proven to be difficult, thus more recently chemotherapeutical treatment options are being considered as a potential alternative to limit the economic impact of neosporosis (Monney and Hemphill, 2014).

In general, chemotherapeutic treatment of Neospora-seropositive animals has not been regarded as an economically viable option, especially since depending on the compounds used, milk or meat from drug-treated animals would remain unacceptable for consumption for some time (Dubey, et al., 2007). Nevertheless, experimental studies have revealed potentially interesting effects of several compounds in vitro and in laboratory animal models in vivo (reviewed in Hemphill et al., 2016). Many of these compounds or compound classes were shown previously to be active against other intracellular protozoan parasites, including Trypanosoma cruzi, the causative agent of Chagas Disease, and Leishmania species responsible for cutaneous and visceral leishmaniasis, and some exhibited broad-spectrum anti-parasitic activity against various protozoans and helminths. However, other approaches identified compounds that inhibited targets that were conserved almost exclusively within the group of apicomplexan parasites. BKIs that target CDPK1 represent a classical example of such a targeted cross-species approach.

Molecular, structural and phenotypic evidence demonstrated that NcCDPK1 is a promising molecular target for neosporosis drug development. Recombinant NcCDPK1 was expressed, purified and screened against a select group of bumped kinase inhibitors (BKIs) previously shown to have low $\mathrm{IC}_{50} \mathrm{~s}$ against $T$. gondii CDPK1 and $T$. gondii tachyzoites. NoCDPK1 was inhibited by low concentrations of BKIs, and BKI-1294 was chosen as a lead compound (Ojo, et al., 2014). The three-dimensional structure of NoCDPK1 in complex with BKI-1294 was studied crystallographically, demonstrating the structural basis for binding and selectivity. Calcium-dependent conformational changes in solution as characterized by small-angle X-ray scattering are consistent with previous structures in low calcium-state but different in the calcium-bound active state than predicted by X-ray crystallography (Ojo, et al., 2014). This implies that additional structural states of CDPK1 exists beyond the $\mathrm{X}$-ray crystallographic structures with and without bound calcium.

The compound interferes in Neospora host cell invasion and egress, and prolonged exposure results in the formation of multinucleated parasites, trapped within host cells (Ojo, et al., 
2014). BKI-1294 exposure in vitro is not directly parasitocidal: only upon long-term in vitro treatment of infected host cells ( $>20$ days), was a complete clearance of viable tachyzoites observed. For different Neospora isolates such Nc-1, Nc-Liv, and Nc-Spain7, but also for $T$. gondii strains RH and ME49, clearance of intracellular parasites is also always preceded by the formation of multinucleated parasites with a deregulated gene expression pattern as evidenced by the simultaneous expression of bradyzoite and tachyzoite antigens (Fig. 4) (Winzer, et al., 2015).

In vivo treatment with BKI-1294 in a standardized neosporosis mouse model (Arranz-Solís, et al., 2015) is highly efficacious in non-pregnant mice: Oral dosing of BKI-1294 at 50 $\mathrm{mg} / \mathrm{kg}$ for 5 days in established murine neosporosis resulted in a 10 -fold reduced cerebral parasite burden compared to untreated controls. In addition, BKI-1294 used at the same dosage did not show any adverse effects in pregnant mice nor in their offspring. BKI-1294 is the first compound tested so far that achieved excellent protection against vertical transmission of $N$. caninum, with only 5\% offspring mortality compared to $100 \%$ in the placebo group, and less than 10\% of offspring PCR positive in the CNS, compared to $100 \%$ positive in the placebo group (Winzer, et al., 2015). Thus, these data demonstrate proof-ofconcept for BKIs, and 1294 specifically, for therapy of bovine and canine neosporosis, and BKI-1294 is a prime candidate for further follow-up studies in larger animals. In addition, other BKIs are currently evaluated in vitro and in vivo.

\subsection{Sarcocystis}

Sarcocystis neurona is the primary causative agent of equine protozoal myeloencephalitis (EPM), which is a serious neurologic disease that impacts horses in North and South America (Dubey, et al., 2015, Howe, et al., 2014). The clinical signs of EPM are variable and can range from acute to chronic, with the potential for neuropathology in all areas of the central nervous system (CNS) although the spinal cord is most commonly affected. EPM horses may exhibit a gradual progression of clinical signs such as mild lameness and asymmetric muscle atrophy, while acutely-affected horses can progress quickly to severe ataxia or recumbency. Without adequate treatment, the disease is typically fatal. Notably, $S$. neurona has also been found to be a significant cause of morbidity and mortality in assorted marine mammals, including sea otters, seals, and sea lions (Carlson-Bremer, et al., 2012, Dubey, et al., 2001, Lapointe, et al., 1998, Lindsay, et al., 2001, Miller, et al., 2010, Rosonke, et al., 1999).

Like its close relatives $T$. gondii and $N$. caninum, S. neurona has an obligatory two-host life cycle that includes the opossums Didelphis virginiana in North America (Fenger, et al., 1995) and Didelphis albiventris in South American (Dubey, et al., 2001) as the definitive host. The natural intermediate hosts are various small mammals such as skunks (Cheadle, et al., 2001), raccoons (Dubey, et al., 2001), and armadillos (Cheadle, et al., 2001). Horses and marine mammals become infected when they ingest $S$. neurona sporocysts/oocysts that have been passed in the feces of infected opossums.

The traditional anti-folate drug combination of pyrimethamine and a sulfonamide has been used for decades to treat EPM, with daily administration for at least six months considered the standard therapy. While rarely serious, the anti-folate drugs can have side effects such as 
bone marrow suppression, anorexia, diarrhea, mild anemia, and neutropenia, and pyrimethamine is a teratogen that should not be given to pregnant mares (Reed, et al., 2016). More recently, diclazuril and ponazuril have been developed and approved for use as a treatment for EPM (Dirikolu, et al., 2006, Furr, et al., 2001, Mackay, et al., 2008). These two drugs have broad anticoccidial activity in a variety of animal species and are benzeneacetonitrile compounds related to the herbicide atrazine (Hackstein, et al., 1995).

Nitazoxanide (NTZ) is a broad-spectrum antimicrobial drug that was approved and marketed for treatment of EPM. Although an effective therapy for treatment of $S$. neurona infection, the broad-spectrum activity of NTZ was associated with adverse side-effects in horses (e.g., colic), so this drug is no longer available for treatment of EPM.

Interrogation of $S$. neurona genome and transcriptome information revealed a CDPK1 homologue with the glycine "gatekeeper" residue found in other apicomplexans, thus implying that BKIs might be effective against $S$. neurona infection and EPM. Detailed examination showed that BKIs bind and inhibit recombinant $S n C D P K 1$ in vitro, and $S$. neurona in cell culture was inhibited by four different BKIs at $\mathrm{EC}_{50}$ values of $40-120 \mathrm{nM}$ (Ojo, et al., 2016). Based on the timing of treatment, it appeared that host cell invasion by the parasite was blocked by the BKIs, consistent with the role of CDPK1 for regulating parasite motility and host cell entry (Lourido, et al., 2010, Lourido, et al., 2012, Ojo, et al., 2010). However, higher BKI concentrations resulted in delayed $S$. neurona endopolygeny and apparent arrest just prior to formation of daughter merozoites. These results suggested that BKI treatment at elevated concentrations might inhibit a second target related to $S$. neurona development and cytokinesis, similar to what was observed for $N$. caninum and $T$. gondii (Ojo, et al., 2014, Winzer, et al., 2015). In vivo experiments in a murine model of sarcocystosis showed that treatment for 30 days with BKI-1553 protected $S$. neuronachallenged mice. In contrast, challenged and non-treated control mice had severe signs of neurologic disease resulting in death or the need for euthanasia between 39 and 70 days post-inoculation. Histologic analysis and bioassay of brain tissues demonstrated parasites in all 10 non-treated control mice but in only 1 of the BKI-1553-treated mice, indicating that BKI treatment cleared infection in $90 \%$ of mice challenged with $S$. neurona. Importantly, BKI-1553 is one of several optimized BKIs lacking the potent hERG inhibitory activity that precluded the use of the initially-developed related BKI-1294 in humans-(Vidadala, et al., 2016). Along with these improvements to reduce host toxicity, the experimental results examining BKI activity against $S$. neurona infection indicate that these compounds are promising candidates for developing a new therapy for horses afflicted with EPM.

\subsection{Cryptosporidium}

Cryptosporidiosis, a zoonotic or anthroponotic disease caused by the apicomplexan parasites of the genus Cryptosporidium, is a significant contributor to global diarrheal morbidity and mortality. Cryptosporidiosis is transmitted in the form of highly resistant, sporulated oocysts that are infectious at the time of passage and spread by the fecal-oral route. Presumptive diagnoses of Cryptosporidiosis in calves, for instance, could be made based on age, clinical signs and symptoms. Laboratory diagnosis is mostly based on identifying oocysts in feces. Infection takes root in the host's intestinal epithelial cells and causes watery diarrhea that is typically self-limiting. However, there is a risk for severe disease in immunocompromised 
persons, such as those suffering from AIDS and malnourished children in developing countries, with infection becoming persistent, recurring, and life-threatening (Fayer, 1997). Cryptosporidium has recently been identified as the second and third leading cause of moderate to severe diarrhea in infants aged 0 to 11 months and 12 to 23 months, respectively, in various regions of Africa and South Asia (Kotloff, et al., 2013). Current treatments for cryptosporidiosis, including nitazoxanide and paromomycin, have marginal efficacy of 1.7 days less diarrhea in normal hosts. These drugs are largely ineffective in immunocompromised patients and are not approved for use in children under 12 months old (Pantenburg, et al., 2009), the two groups most at risk from this disease, underscoring the urgent need for novel therapeutics.

Like $T g C D P K 1, C$. parvum CDPK1 (CpCDPK1) contains a glycine residue at the gatekeeper position (Murphy, et al., 2010). For this reason and because of the homology of the solved crystal structures of the ATP binding sites of $T g$ and $C p$ CDPK1, BKIs synthesized to target $\mathrm{T} g \mathrm{CDPK} 1$ have been analyzed for activity against $C p \mathrm{CDPK} 1$. BKIs were evaluated in vitro to determine enzymatic $\mathrm{IC}_{50} \mathrm{~s}$ against $C p C D P K 1$ and cellular $\mathrm{EC}_{50} \mathrm{~s}$ against $C$. parvum cultured in HCT-8 cells. Three of the most potent compounds were the PP compounds BKI-1294 and BKI-1553, and the AC compound BKI-1517 (Fig. 3) (Castellanos-Gonzalez, et al., 2016, Castellanos-Gonzalez, et al., 2013, Schaefer, et al., 2016). These compounds were subsequently assessed in vivo for efficacy in various mouse and calf models.

SCID-beige mice infected by oral gavage with $C$. parvum were dosed P.O. with BKI-1294 at $100 \mathrm{mg} / \mathrm{kg}$ or vehicle alone for 10 days (4-14 days post-infection). Those treated with BKI-1294 showed significant reduction in oocyst shedding and eventual clearance, with only 1 of 7 mice shedding oocysts by 33 days post-infection compared to 6 of 7 control mice shedding at 33 days post infection (Castellanos-Gonzalez, et al., 2013). Hematoxylin-eosin stained sections of intestine from mice treated with 1294 displayed a lack of damage to the intestinal epithelium and a lack of excess apoptotic cells, both of which were observed in the C. parvum infected control mice but absent in uninfected controls (Castellanos-Gonzalez, et al., 2013). Similarly, mice treated with BKI-1517 at $60 \mathrm{mg} / \mathrm{kg}$ and $120 \mathrm{mg} / \mathrm{kg}$ P.O. for 5 days also showed significant reduction in oocyst shedding (Castellanos-Gonzalez, et al., 2016). At the higher dose, infection was completely cleared out to 28 days post-infection in 5 of 6 mice; at the lower dose infection was reduced, with only 3 of 6 mice shedding oocysts at 28 days (Castellanos-Gonzalez, et al., 2016).

Lead BKIs were also screened in vivo against $C$. parvum infection in neonatal ICR mice (Schaefer, et al., 2000, Schaefer, et al., 2016). Eight day old mice received a dose of 25 $\mathrm{mg} / \mathrm{kg}$ of BKI concurrently with infection, then dosed again at 3 hours post-infection (HPI) and every 12 hours thereafter for nine total doses. Histological examination of the jejunum, ileum, cecum, and colon showed a $56 \%, 38 \%$, and $36 \%$ reduction of infection in mice treated with BKI-1294, BKI-1517, BKI-1553 respectively, or (Schaefer, et al., 2016). Paramomycin treatment of neonates showed significantly lower efficacy, with a reduction of $15 \%$ (Schaefer, et al., 2016). 
The same three BKIs were next evaluated in a clinical disease model, treating neonatal calves infected with $C$. parvum at 36 to 48 hours old (Imboden, et al., 2012, Schaefer, et al., 2016). BKI-1294 was dosed in two different groups: group A was given 4 doses total at 10 $\mathrm{mg} / \mathrm{kg}$, once daily at 48, 96,144, and 192 hours-post-infection (HPI); and group B was given 10 doses total at $5 \mathrm{mg} / \mathrm{kg}$ every 12 hours 48 - $156 \mathrm{HPI}$. Treatment group A showed improvement in daily clinical health scores, increased total urine output, and firmer fecal consistency, in addition to reduced weight loss and fewer oocysts shed daily when compared to controls (Schaefer, et al., 2016). However, while this treatment did not reduce total fecal output when compared to controls, drug concentrations in plasma and stool were subsequently determined by LC-MS analysis to be below therapeutic levels (essentially zero) by 48 hours after each dose (Schaefer, et al., 2016). This partial success inspired the repeat trial, dosing BKI-1294 at 12 hour intervals (group B), which showed significant improvements over control calves in daily clinical health scores, decreased duration of diarrhea, decreased total fecal output and firmer fecal consistency, decreased weight loss, and decreased number of oocysts shed (Schaefer, et al., 2016). BKIs 1517 and 1553 were also dosed a total of 10 times at 12 hour intervals starting at $48 \mathrm{HPI}$ at $10 \mathrm{mg} / \mathrm{kg}$ and 5 $\mathrm{mg} / \mathrm{kg}$, respectively. Both also showed significant improvements over control calves in all parameters when dosed every 12 hours, with the single exception that BKI-1553 failed to reduce total fecal volume (Schaefer, et al., 2016). Neonatal calf studies showed that, overall, all three BKIs reduced cryptosporidiosis symptoms and infection levels, with BKIs 1294 and 1517 showing slightly better outcomes compared to BKI-1553 (Schaefer, et al., 2016).

\subsection{Plasmodium}

Malaria remains a major cause of morbidity, afflicting over two hundred million people annually (World Health Organization., 2014). Despite years of exposure to intense malaria transmission; individuals living in endemic areas have no evidence of sterile immunity to $P$. falciparum infection (Tran, et al., 2013). Infections are transmitted through bites of infected female Anopheles mosquitoes. Infection of humans is primarily due to four Plasmodium species, namely $P$. falciparum, $P$. vivax. $P$. malariae, and $P$. ovale. A fifth species, $P$. knowlesi, emerging in Malaysia, is reported to cause a zoonotic malaria in humans (Jongwutiwes, et al., 2004). Malaria parasites alternate between different stages in both mammalian (asexual) and mosquito (sexual) hosts. Currently used drugs for treatment of clinical symptoms of malaria erythrocytic (asexual) stage do not prevent the sexual forms (gametocytes) from infecting mosquitoes, even when prevalence and density of gametocytes appear low (Schneider, et al., 2006). Even treatment with the two drugs with anti-gametocyte activity, primaquine and artemisinin combination therapy, are imperfect in stopping Plasmodium transmission to mosquitoes. Primaquine kills mature but not immature gametocytes, while artemisinin combination therapy kills immature but not mature gametocytes (Bousema and Drakeley, 2011, Wilairatana, et al., 2010). Atovaquone was recently shown to as a strong inhibitor of $P$. berghei ookinete formation (Delves, et al., 2012) which makes it a good candidate for malaria transmission blocking indication.

The lack of effective transmission-blocking gametocides is a problem for malaria control because circulating gametocytes that are infectious to mosquitoes persist for weeks after anti-malarial therapy (Bousema and Drakeley, 2011, Bousema, et al., 2010). Treated 
individuals, often without symptoms, continue to transmit malaria to abundant mosquitos, since effective control of Anopheles mosquitoes also remains a formidable challenge (Wellems, et al., 2009). This emphasizes the need for interventions that prevent parasite transmission.

Transmission of malaria parasites and effective transition between these different stages of life in mammalian and mosquito hosts require elaborately coordinated signal transduction (Ojo, et al., 2012, Vidadala, et al., 2014). Controlled shifts between high and low levels in intracellular calcium concentrations have been speculated to influence many of these processes. Intracellular calcium levels in infectious apicomplexan parasites have long been associated with invasion, gliding motility, and the secretory pathway; elements that are likely interrelated (Nagamune and Sibley, 2006). We have recently developed an extended spectrum class of BKIs to disrupt the transmission of malaria parasites from humans to mosquitos. It has been demonstrated using chemical genetics that the mechanism of action of these BKIs is through inhibition of Plasmodium calcium dependent protein kinase 4 (CDPK4) (Ojo, et al., 2014, Ojo, et al., 2012). Previous studies have shown that BKIs, when ingested by mosquitoes during a blood meal containing malaria gametocytes, inhibit CDPK4 activity and this prevents exflagellation of the male gametocytes (Ojo, et al., 2014, Ojo, et al., 2012). Exflagellation is the visible outcome of the maturation and activation of male gametocytes into sperm-like, male gamete cells needed for fertilization of the female gametes. In simple terms, BKIs act as malaria birth control pills that stop the transmission of malaria by blocking the mating and further parasite development to infectious stages in the mosquito. Thus, BKIs could fill an important but often overlooked gap in malaria control. To block transmission, BKIs must be present in the blood constantly while gametocytes are present and when a mosquito bites. These parameters therefore require that the inhibitor needs to be non-toxic, long lasting, and effective at doses that permit long-term treatment exposure in humans. Highly selective transmission blocking BKIs (Ojo, et al., 2014, Ojo, et al., 2012, Vidadala, et al., 2014) were successfully designed because the serine gatekeeper residue in Plasmodium CDPK4 is smaller than that of almost all human kinases. Additional specificity and potency was provided by the unique conformation of the active site and hydrogen-bonding sites available to small molecule inhibitors, as well as structural features that can be exploited to gain further selectivity, as discussed in detail above (Ojo, et al., 2014, Ojo, et al., 2012, Vidadala, et al., 2014). Specific inhibition of CDPK4 does not appear to inhibit the asexual blood stages of malaria since most of the asexual stage activity was lost from our BKI series during optimization for CDPK4 kinase activity and specificity (Ojo, et al., 2014, Ojo, et al., 2012, Vidadala, et al., 2014). This is important in preventing the evolution of resistance to BKI drugs. Drugs with activity against asexual parasites regularly contact their targets in the $10^{11}$ to $10^{12}$ asexual stage parasites in each person, increasing the chance of encountering (and selecting) a resistant parasite. Because only about 10 gametocytes are taken up by each mosquito, and BKIs only act against gametocytes in the mosquito, the likelihood of BKIs encountering a resistant parasite is extremely low. Thus BKIs could be part of a malaria combination therapy that could stop transmission of parasites that become resistant to the other components that alleviate the malaria illness.

The active sites of Plasmodium spp. CDPK4 enzymes are highly homologous. We have demonstrated that BKIs block both rodent and human malaria transmission to mosquitoes 
(Ojo, et al., 2012). This data suggests that BKIs and related compounds are likely to be useful in blocking the transmission of all five species known to cause human malaria; a significant public health benefit.

\subsection{Babesia}

Babesiosis is a zoonotic disease caused by the apicomplexan genus, Babesia. With more than 100 species currently recognized, these hemoparasitic protozoans inflict asymptomatic, mild to fatal diseases to a large diversity of animals including humans. The most economically devastating disease is bovine babesiosis. Two major Babesia species, B. bovis and $B$. bigemina, are responsible for this significant agricultural problem with the latter species causing a milder illness to livestock. Most often exhibited symptoms are the characteristic high fever, anemia, anorexia, hemoglobinuria with periodic neurological sequelae such as incoordination, tilting of the head, teeth grinding, involuntary movements of the legs and excess salivation caused by B. bovis. In severe and often fatal cases, B. bovisinfected animals eventually suffer from cerebral babesiosis. Bovine babesiosis is a disease of the adult animals as juveniles are immune until they are at least 6-8 months old (Brown, et al., 2006, Taylor, et al., 1983). It is endemic to most of the world, and the distribution of the disease is entirely dependent upon the geographical localization of the tick vector, Rhipicephalus sp. Countries in Asia, South America, Australia, Europe and Africa are all affected. North America such as the US is almost devoid of bovine babesiosis due to an effective, well-coordinated tick eradication program that started in the 1940s. However, an increase in acaricide resistance of the tick vector and global animal movement are contributing to the re-emergence of bovine babesiosis in the US. In contrast to animal babesiosis, human babesiosis, caused by B. microti, has not always been on the radar of disease surveillance in the US. This tick-borne disease is currently a public health issue, especially in the Northeast corridor of the US. There, B. microti shares its vector host with Borrelia sp., the causative agent of Lyme disease. Thus, it has been reported that some Lyme disease patients also suffer from human babesisosis (Diuk-Wasser, et al., 2016, Knapp and Rice, 2015).

There has been substantial research effort and financial funding over the years to develop preventive and chemotherapeutic remedies against babesiosis for the veterinary and medical world. Currently, live attenuated vaccines are available for combating veterinary babesiosis and are widely used in endemic countries such as Australia and Argentina (Gohil, et al., 2013). For non-endemic countries such as the United States where treatment is the preferred option, imidocarb dipropionate $(3.5 \mathrm{mg} / \mathrm{kg})$ intramuscularly administered is effective although residual drug metabolite renders the treated animal unmarketable (Coldham, et al., 1995). For human babesiosis, antibiotic combination therapy is available (Homer, et al., 2000). However, due to side effects and long treatment regimen, improved treatment therapies are desired (Vannier, et al., 2015).

BKIs have been established to be specifically inhibitory against apicomplexans such as Plasmodium, Toxoplasma and Cryptosporidium (see above). Out of $>600$ of these BKIs available for testing, a subset was chosen to evaluate if they would inhibit Babesia growth within the mammalian host (Keyloun, et al., 2014). Using the B. bovis model system to 
evaluate the drug effect, 12 BKIs were selected and added to the growth media of the parasite culture (Pedroni, et al., 2016). As expected, inhibition ranged from non-responsive to lethal as compared to the control group. Of the BKIs that were inhibitory, their antiproliferative action was observed as early as 24 hours post-treatment. No specific cellular phenotypic effect was observed, except for BKI-RM-1-152, which $30 \mu \mathrm{M}$ constant exposure blocked egress from the infected erythrocytes, as parasites continued to replicate and accumulate, an observation shared with the Neospora parasites that are exposed to BKI-1294 in vitro. This resulted in the accumulation of merozoite-like parasites crowding within the host erythrocyte although the overall erythrocyte size remained unchanged (Pedroni, et al., 2016). BKI-RM-1-152's effect was specific to the egression process as the removal of the drug led to successful egress of these merozoite-like parasites and the freed merozoites invaded more host cells. This result illustrated the static nature of this particular BKI.

BKIs clearly have a negative effect on Babesia and can be further exploited for the development of an effective, specific treatment option against babesiosis. Identification of the specific BKI target(s) in Babesia and subsequent optimization of the binding affinity of the BKIs to these targets are logical next steps. These small compounds may also assist in deciphering cellular pathways of Babesia such as egress, invasion and replication, where these and many other metabolic pathways remain a significant knowledge gap in this parasite field.

\subsection{Theileria}

Theileria equi is a tick-transmitted apicomplexan hemoprotozoan parasite of equids and an etiologic agent of equine piroplasmosis (EP), a World Organization for Animal Health (OIE) reportable disease. T. equi occurs worldwide where tick vectors are present, and it is estimated that only $10 \%$ of the world's equids reside in regions free of EP (de Waal, 1992). Although the continental USA was declared free of EP in 1988 (United States. Animal and Plant Health Inspection Service., 2008), several well-described outbreaks of T. equi have occurred recently in U.S. horses (Scoles, et al., 2011, Short, et al., 2012, Ueti, et al., 2012, United States. Animal and Plant Health Inspection Service., 2008).

Although prevention of infection and disease would be ideal, complete control of tick vectors is extremely difficult, and vaccines against $T$. equi do not exist. Treatment of infected animals with the goal to clear infection and eliminate the risk of transmission represents a feasible strategy for disease control in some regions. Imidocarb dipropionate, a dicationic diamidine of the carbanilide series of antiprotozoal compounds, has been effective against some of the T. equi strains causing infections in U.S. horses (Ueti, et al., 2012), making it the current drug of choice. However, variable responses to imidocarb treatment occur in both natural and experimental T. equi infection (Butler, et al., 2008, Frerichs, et al., 1973, Grause, et al., 2013, Knowles, 1996, Kumar, et al., 2003, Kumar, et al., 2009, Kuttler, et al., 1987, Ueti, et al., 2012), and we have recently documented treatment failure associated with in vitro imidocarb resistance (Hines, et al., 2015). Moreover, acute adverse effects are common due to the anticholinesterase activity of the drug (Tecles and Cerón, 2001). These include spasmodic colic and diarrhea (Meyer, et al., 2005). Therefore, pretreatment with anticholinergic drugs such as atropine sulfate (Meyer, et al., 2005), glycopyrrolate 
(Donnellan, et al., 2013), or N-butylscopolammonium bromide (Ueti, et al., 2012) is required. Imidocarb injections are painful and local injection site reactions are common (Meyer, et al., 2005). The $\mathrm{LD}_{50}$ is $16 \mathrm{mg} / \mathrm{kg}$ (only four times the therapeutic dose), and death is associated with dose-dependent nephrotoxicity and hepatotoxicity (Adams, 1981).

Because of the documented effectiveness of BKIs against other apicomplexans (reviewed herein), we recently evaluated the in vitro susceptibility of several $T$. equi isolates to both imidocarb dipropionate and to BKI-1294 (Hines, et al., 2015). Similar to other apicomplexans, T. equi CDPK1 has a small glycine gatekeeper residue within the ATPbinding region (Hines, et al., 2015). Despite a difference in imidocarb susceptibility amongst isolates $\left(\mathrm{EC}_{50}: 6.4-414 \mathrm{nM}\right.$ ), we observed uniform susceptibility to BKI-1294, albeit at a considerably higher $\mathrm{IC}_{50}$ of approximately $4.0 \mu \mathrm{M}$. The relatively high hERG activity of BKI-1294 (IC $50: 0.767 \mu \mathrm{M})(\mathrm{Ojo}$, et al., 2014) likely precludes its use in the horse for treating T. equi, especially given recent work documenting the sequence and functional homology of the equine hERG ortholog (Pedersen, et al., 2015). Ongoing work includes screening additional BKI compounds for those with higher activity against $T$. equi coupled with lower to absent hERG activity. Given the large number of recently developed BKI compounds, it is possible that a promising nontoxic alternative to imidocarb dipropionate will be identified for the treatment of horses infected with $T$. equi.

\subsection{PK and Safety of Lead BKIs}

Single Dose-While the efficacy of our BKIs against CDPK1 and apicomplexan parasites are similar for the lead drug candidates, these compounds display diverse in vivo efficacy in each of the animal models. It is possible that the in vivo variability in BKI efficacy may be related to their absorption, distribution, metabolism, and elimination (ADME) properties. Indeed the pharmacodynamics for BKIs against $T$. gondii and $C$. parvum might be expected to be completely different, as $T$. gondii need to be treated by a systemically-distributed compound with blood-brain-barrier permeability, whereas $C$. parvum therapy would need to reach the large bowel, where $C$. parvum resides on the apical side of intestinal epithelial cells. In our evaluation pipeline, we initially characterized the pharmacokinetics of BKIs by administering a $10 \mathrm{mg} / \mathrm{kg}$ P.O. dose to BALB/c mice. In addition, a single $25 \mathrm{mg} / \mathrm{kg}$ P.O. dose of BKI was administered to characterize the fecal levels of the compounds.

The pharmacokinetic data for our three lead BKIs in adult BALB/c mice indicate that BKIs 1517 and 1553 have higher systemic peak plasma concentrations $\left(\mathrm{C}_{\max }\right)$ and plasma exposures (AUC) compared to BKI-1294 (Table 1) (Huang, et al., 2015, Vidadala, et al., 2016). BKI-1553 is more tightly bound to plasma proteins than the other two BKIs in mouse plasma. In addition, BKI-1553 has the largest systemic exposure; over four-fold greater than BKI-1517, largely because BKI-1517 is cleared more rapidly than BKI-1553.At this time it is unclear whether systemic concentrations drive the in vivo efficacy of BKIs for cryptosporidiosis (which is restricted to the gut), though the correlation is quite tight for toxoplasmosis. Therefore, it is important to note that in a mouse single dose model (25 $\mathrm{mg} / \mathrm{kg}$ P.O.), the fecal concentrations of BKI-1294 are greater than BKIs 1553 and 1517 (Schaefer, et al., 2016). 
The bioavailability of BKIs 1294 and 1553 was evaluated by characterizing the pharmacokinetics of each BKI after intravenous (I.V.) and P.O. dosing in rats. Following I.V. administration to rats, BKI-1553 displayed biphasic kinetics and distributed approximately to total body water with a volume of distribution at steady state $\left(\mathrm{V}_{\mathrm{ss}}\right)$ of $0.9 \mathrm{~L} / \mathrm{kg}$. Following P.O. administration to rats, BKI-1553 showed slow absorption, with the absorption phase continuing for 12 hours. The plasma concentrations over the 24 hour period after P.O. dosing exceeded those observed after I.V. dosing suggesting that BKI-1553 had essentially complete bioavailability in rats and was greatly improved compared to that of BKI-1294 (46\%). Additional studies with BKI-1553 demonstrate that BKI-1553 has a bioavailability of $86 \%$ in dogs and $65 \%$ in monkeys. Why the bioavailability of BKI-1553 is higher in mice compared to dogs and monkeys is not clear at this time.

In addition to mice, we have used calves as a pharmacokinetic and efficacy model for BKIs. The pharmacokinetics of BKIs 1294, 1517, and 1553 were determined after a single P.O. dose $(10 \mathrm{mg} / \mathrm{kg}$ ) (Schaefer, et al., 2016, Vidadala, et al., 2016). Similar to the results observed in the mouse model, BKI-1553 had the highest $\mathrm{C}_{\max }$ value and largest AUC (Table 2) (Vidadala, et al., 2016). In addition, the rank order of $t_{1 / 2}$ was the same in mice and calves. However, unlike the mouse model, BKI-1294 has a smaller oral clearance than BKI-1517 in the calf model, which results in an increased systemic exposure of BKI-1294 compared to BKI-1517 (Schaefer, et al., 2016, Vidadala, et al., 2016). Differences in bioavailability between the animal models are possible explanation for this disparity.

Multiple Dosing-Tolerability and linear pharmacokinetics for BKI-1553 were evaluated after multiple doses in a mouse model. BKI-1553 was administered at $50 \mathrm{mg} / \mathrm{kg}$ every other day for 5 doses to mice, and plasma concentrations remained $>10 \mu \mathrm{M}$ for the entire duration of the study with maximum concentrations reaching $43 \mu \mathrm{M}$ (Vidadala, et al., 2016). The exposure to BKI-1553 following the last $50 \mathrm{mg} / \mathrm{kg}$ dose was higher than what would be predicted from the single dose studies. The longer $\mathrm{t}_{1 / 2}$ suggests possible saturation of metabolism at this dose. A final blood collection was performed at the end of the study and all blood chemistry results were reported by Phoenix Central Laboratory to be within a normal range for species and age.

In addition to mice, the pharmacokinetics of BKIs 1294, 1553, and 1517 were characterized after multiple doses of BKI to calves. Calves were dosed separately P.O. with either $5 \mathrm{mg} / \mathrm{kg}$ (BKIs 1294 or 1553) or $10 \mathrm{mg} / \mathrm{kg}$ (BKI-1517) twice a day for five days (Schaefer, et al., 2016). Overall, the steady state concentrations observed in the calves were within twofold of those predicted from the single dose data. As expected, steady state plasma concentrations for BKI-1553 were approximately 25-fold higher than BKIs 1294 and 1517(Schaefer, et al., 2016). The ability to accurately predict the steady state concentrations of each BKI indicates that there is no saturation of metabolism with these dosing conditions. Furthermore, even during infection steady state concentrations for BKIs 1517 and 1553 could be accurately predicted using the single dose data from healthy calves. This suggests that the disease pathology does not have a significant impact on systemic concentrations of BKI, although further studies are warranted. 
Toxicity-BKIs 1294, 1553, and 1517 were initially screened for cytotoxicity against two mammalian cell lines HepG2 (liver) and CRL-8155 (lymphoblast). None of these three BKIs display any signs of toxicity at concentrations of up to $30 \mu \mathrm{M}$. In vivo toxicity for BKI-1294 was initially screened by dosing at $40 \mathrm{mg} / \mathrm{kg}$ three times a day, and the mice appeared healthy. In addition, BKI-1294 was not toxic when dosed P.O. at $100 \mathrm{mg} / \mathrm{kg}$ daily for 5 days. Potential toxicity of BKI-1553 was examined in mice by testing two doses $(30 \mathrm{mg} / \mathrm{kg}$ and $100 \mathrm{mg} / \mathrm{kg}$ P.O.) daily for 5 days while observing mice for signs of toxicity and collecting blood samples. Both groups of mice remained active, well-groomed and appeared healthy throughout the study. Upon necropsy, there were no gross abnormalities, but histology revealed mild focal inflammation in the spleen in two of three mice in the $30 \mathrm{mg} / \mathrm{kg}$ group. The only abnormality observed in the $100 \mathrm{mg} / \mathrm{kg}$ group was inflammatory infiltrate in the hepatic lobules in one of three mice. BKI-1517 was dosed at $100 \mathrm{mg} / \mathrm{kg}$ once a day for 5 days. Over days $2-5$ the mice became less groomed and demonstrated less activity. When the dose was reduced to $53 \mathrm{mg} / \mathrm{kg}$ on day 1 and then $26.5 \mathrm{mg} / \mathrm{kg}$ once a day for four days, the mice remained well-groomed and healthy on each day.

We completed a maximally tolerated dose study to determine the lowest observable adverse effect level (LOAEL) and the no observable adverse effect level (NOAEL) of BKI-1553. Mice were dosed with single P.O. doses ranging from $200 \mathrm{mg} / \mathrm{kg}$ to $1000 \mathrm{mg} / \mathrm{kg}$. The LOAEL was observed at $500 \mathrm{mg} / \mathrm{kg}$, and the NOAEL was observed at $400 \mathrm{mg} / \mathrm{kg}$. Mice had slightly ruffled fur and were less active than the control mice at $3 \mathrm{~h}$ following the $500 \mathrm{mg} / \mathrm{kg}$ dose. The lowered activity persisted at 24 hours, but was resolved by 30 hours. In addition, toxicity in calves was not observed for BKIs 1294 1517, or 1553, but the doses used were much lower (Schaefer, et al., 2016).

\section{Conclusion}

This review has focused on the utility of BKIs for therapy and prevention of apicomplexan infections. It is clear that the BKIs will have great utility against those organisms with the smallest gatekeepers in their CDPK1s, such as T. gondii, $N$. caninum, S. neurona, and Cryptosporidium spp (Table 3). Nonetheless, the optimal pharmacodynamics of treatment for Cryptosporidium spp., which are found in the greatest number in the proximal large bowel and reside on the tips of epithelial cells and project into the lumen of the gut, are expected to be quite different compared to T. gondii, $N$. caninum, and $S$. neurona, which cause systemic infection. Gut exposure is probably of primary importance for Cryptosporidium therapy, but broad systemic distribution is necessary for treatment of $T$. gondii, $N$. caninum, and $S$. neurona infections The apicomplexan organisms whose essential CDPKs have larger gatekeeper residues, such as threonine, are more difficult to inhibit selectively, yet the relatively poor choices of current therapeutics encourage us to continue development of BKIs for these pathogens. The encouraging results and long lasting plasma levels of BKIs give us optimism that BKIs can be developed to stop transmission of malaria.

\section{Acknowledgments}

This work was supported by the US National Institutes of Health (NICHHD R01HD080670 \& NIAID R01AI111341, R01AI089441) and the USDA (2014-06183). This work was also supported by Swiss National 
Science Foundation (grant No. 310030_165782) and in part by Career Development Award \# BX002440 to J. Stone Doggett from the United States Department of Veterans Affairs Biomedical Laboratory Research and Development.

\section{References}

1. Panel on Opportunistic Infections in HIV-Infected Adults and Adolescents. Guidelines for the prevention and treatment of opportunistic infections in HIV-infected adults and adolescents: recommendations from the Centers for Disease Control and Prevention, the National Institutes of Health, and the HIV Medicine Association of the Infectious Diseases Society of America.

2. Adams LG. Clinicopathological aspects of imidocarb dipropionate toxicity in horses. Res Vet Sci. 1981; 31:54-61. [PubMed: 7313320]

3. Arranz-Solís D, Aguado-Martínez A, Müller J, Regidor-Cerrillo J, Ortega-Mora LM, Hemphill A. Dose-dependent effects of experimental infection with the virulent Neospora caninum Nc-Spain7 isolate in a pregnant mouse model. Vet Parasitol. 2015; 211:133-140. [PubMed: 26104964]

4. Bishop AC, Buzko O, Shokat KM. Magic bullets for protein kinases. Trends Cell Biol. 2001; 11:167-172. [PubMed: 11306297]

5. Bishop AC, Shah K, Liu Y, Witucki L, Kung C, Shokat KM. Design of allele-specific inhibitors to probe protein kinase signaling. Curr Biol. 1998; 8:257-266. [PubMed: 9501066]

6. Bishop AC, Shokat KM. Acquisition of inhibitor-sensitive protein kinases through protein design. Pharmacology \& Therapeutics. 1999; 82:337-346. [PubMed: 10454210]

7. Bishop AC, Ubersax JA, Petsch DT, Matheos DP, Gray NS, Blethrow J, Shimizu E, Tsien JZ, Schultz PG, Rose MD, Wood JL, Morgan DO, Shokat KM. A chemical switch for inhibitorsensitive alleles of any protein kinase. Nature. 2000; 407:395-401. [PubMed: 11014197]

8. Bousema T, Drakeley C. Epidemiology and infectivity of Plasmodium falciparum and Plasmodium vivax gametocytes in relation to malaria control and elimination. Clin Microbiol Rev. 2011; 24:377410. [PubMed: 21482730]

9. Bousema T, Okell L, Shekalaghe S, Griffin JT, Omar S, Sawa P, Sutherland C, Sauerwein R, Ghani AC, Drakeley C. Revisiting the circulation time of Plasmodium falciparum gametocytes: molecular detection methods to estimate the duration of gametocyte carriage and the effect of gametocytocidal drugs. Malaria Journal. 2010:9. [PubMed: 20064223]

10. Brown WC, Norimine J, Knowles DP, Goff WL. Immune control of Babesia bovis infection. Vet Parasitol. 2006; 138:75-87. [PubMed: 16510249]

11. Butler CM, Nijhof AM, van der Kolk JH, de Haseth OB, Taoufik A, Jongejan F, Houwers DJ. Repeated high dose imidocarb dipropionate treatment did not eliminate Babesia caballi from naturally infected horses as determined by PCR-reverse line blot hybridization. Vet Parasitol. 2008; 151:320-322. [PubMed: 18160222]

12. Carlson-Bremer DP, Gulland FM, Johnson CK, Colegrove KM, Van Bonn WG. Diagnosis and treatment of Sarcocystis neurona-induced myositis in a free-ranging California sea lion. J Am Vet Med Assoc. 2012; 240:324-328. [PubMed: 22256850]

13. Castellanos-Gonzalez A, Sparks H, Nava S, Huang W, Zhang Z, Rivas K, Hulverson MA, Barrett LK, Ojo KK, Fan E, Van Voorhis WC, White AC Jr. A Novel Calcium-Dependent Kinase Inhibitor, Bumped Kinase Inhibitor 1517, Cures Cryptosporidiosis in Immunosuppressed Mice. J Infect Dis. 2016; 214:1850-1855. [PubMed: 27738055]

14. Castellanos-Gonzalez A, White AC, Ojo KK, Vidadala RS, Zhang Z, Reid MC, Fox AM, Keyloun KR, Rivas K, Irani A, Dann SM, Fan E, Maly DJ, Van Voorhis WC. A novel calcium-dependent protein kinase inhibitor as a lead compound for treating cryptosporidiosis. J Infect Dis. 2013; 208:1342-1348. [PubMed: 23878324]

15. Chapman TM, Osborne SA, Bouloc N, Large JM, Wallace C, Birchall K, Ansell KH, Jones HM, Taylor D, Clough B, Green JL, Holder AA. Substituted imidazopyridazines are potent and selective inhibitors of Plasmodium falciparum calcium-dependent protein kinase 1 (PfCDPK1). Bioorg Med Chem Lett. 2013; 23:3064-3069. [PubMed: 23570789]

16. Chapman TM, Osborne SA, Wallace C, Birchall K, Bouloc N, Jones HM, Ansell KH, Taylor DL, Clough B, Green JL, Holder AA. Optimization of an imidazopyridazine series of inhibitors of Plasmodium falciparum calcium-dependent protein kinase 1 (PfCDPK1). J Med Chem. 2014; 57:3570-3587. [PubMed: 24689770] 
17. Cheadle MA, Tanhauser SM, Dame JB, Sellon DC, Hines M, Ginn PE, MacKay RJ, Greiner EC. The nine-banded armadillo (Dasypus novemcinctus) is an intermediate host for Sarcocystis neurona. Int J Parasitol. 2001; 31:330-335. [PubMed: 11306111]

18. Cheadle MA, Yowell CA, Sellon DC, Hines M, Ginn PE, Marsh AE, Dame JB, Greiner EC. The striped skunk (Mephitis mephitis) is an intermediate host for Sarcocystis neurona. Int J Parasitol. 2001; 31:843-849. [PubMed: 11403777]

19. Coldham NG, Moore AS, Dave M, Graham PJ, Sivapathasundaram S, Lake BG, Sauer MJ. Imidocarb residues in edible bovine tissues and in vitro assessment of imidocarb metabolism and cytotoxicity. Drug Metab Dispos. 1995; 23:501-505. [PubMed: 7600919]

20. Dannemann B, McCutchan JA, Israelski D, Antoniskis D, Leport C, Luft B, Nussbaum J, Clumeck $\mathrm{N}$, Morlat P, Chiu J, et al. Treatment of toxoplasmic encephalitis in patients with AIDS. A randomized trial comparing pyrimethamine plus clindamycin to pyrimethamine plus sulfadiazine. The California Collaborative Treatment Group. Ann Intern Med. 1992; 116:33-43. [PubMed: 1727093]

21. de Waal DT. Equine piroplasmosis: a review. Br Vet J. 1992; 148:6-14. [PubMed: 1551016]

22. Delves M, Plouffe D, Scheurer C, Meister S, Wittlin S, Winzeler EA, Sinden RE, Leroy D. The activities of current antimalarial drugs on the life cycle stages of Plasmodium: a comparative study with human and rodent parasites. PLoS Med. 2012; 9:e1001169. [PubMed: 22363211]

23. Dirikolu L, Karpiesiuk W, Lehner AF, Hughes C, Woods WE, Harkins JD, Boyles J, Atkinson A, Granstrom DE, Tobin T. New therapeutic approaches for equine protozoal myeloencephalitis: pharmacokinetics of diclazuril sodium salts in horses. Vet Ther. 2006; 7:52-63. 72. [PubMed: 16598684]

24. Diuk-Wasser MA, Vannier E, Krause PJ. Coinfection by Ixodes Tick-Borne Pathogens: Ecological, Epidemiological, and Clinical Consequences. Trends Parasitol. 2016; 32:30-42. [PubMed: 26613664]

25. Doggett JS, Ojo KK, Fan E, Maly DJ, Van Voorhis WC. Bumped kinase inhibitor 1294 treats established Toxoplasma gondii infection. Antimicrob Agents Chemother. 2014; 58:3547-3549. [PubMed: 24687502]

26. Donnellan CM, Page PC, Nurton JP, van den Berg JS, Guthrie AJ. Comparison of glycopyrrolate and atropine in ameliorating the adverse effects of imidocarb dipropionate in horses. Equine Vet $\mathrm{J}$. 2013; 45:625-629. [PubMed: 23461655]

27. Dubey JP, Dubey J. Review of Neospora caninum and neosporosis in animals. Korean J Parasitol. 2003; 41:1-16. [PubMed: 12666725]

28. Dubey JP, Howe DK, Furr M, Saville WJ, Marsh AE, Reed SM, Grigg ME. An update on Sarcocystis neurona infections in animals and equine protozoal myeloencephalitis (EPM). Vet Parasitol. 2015; 209:1-42. [PubMed: 25737052]

29. Dubey JP, Lago EG, Gennari SM, Su C, Jones JL. Toxoplasmosis in humans and animals in Brazil: high prevalence, high burden of disease, and epidemiology. Parasitology. 2012; 139:1375-1424. [PubMed: 22776427]

30. Dubey JP, Lindsay DS, Kerber CE, Kasai N, Pena HF, Gennari SM, Kwok OC, Shen SK, Rosenthal BM. First isolation of Sarcocystis neurona from the South American opossum, Didelphis albiventris, from Brazil. Vet Parasitol. 2001; 95:295-304. [PubMed: 11223209]

31. Dubey JP, Rosypal AC, Rosenthal BM, Thomas NJ, Lindsay DS, Stanek JF, Reed SM, Saville WJ. Sarcocystis neurona infections in sea otter (Enhydra lutris): evidence for natural infections with sarcocysts and transmission of infection to opossums (Didelphis virginiana). J Parasitol. 2001; 87:1387-1393. [PubMed: 11780826]

32. Dubey JP, Saville WJ, Stanek JF, Lindsay DS, Rosenthal BM, Oglesbee MJ, Rosypal AC, Njoku CJ, Stich RW, Kwok OC, Shen SK, Hamir AN, Reed SM. Sarcocystis neurona infections in raccoons (Procyon lotor): evidence for natural infection with sarcocysts, transmission of infection to opossums (Didelphis virginiana), and experimental induction of neurologic disease in raccoons. Vet Parasitol. 2001; 100:117-129. [PubMed: 11698157]

33. Dubey JP, Schares G, Ortega-Mora LM. Epidemiology and control of neosporosis and Neospora caninum. Clin Microbiol Rev. 2007; 20:323-367. [PubMed: 17428888]

34. Fayer, R. Cryptosporidium and cryptosporidiosis. CRC Press; Boca Raton: 1997. 
35. Fenger CK, Granstrom DE, Langemeier JL, Stamper S, Donahue JM, Patterson JS, Gajadhar AA, Marteniuk JV, Xiaomin Z, Dubey JP. Identification of opossums (Didelphis virginiana) as the putative definitive host of Sarcocystis neurona. J Parasitol. 1995; 81:916-919. [PubMed: 8544064]

36. Frerichs WM, Allen PC, Holbrook AA. Equine piroplasmosis (Babesia equi): therapeutic trials of imidocarb dihydrochloride in horses and donkeys. Vet Rec. 1973; 93:73-75. [PubMed: 4748680]

37. Furr M, Kennedy T, MacKay R, Reed S, Andrews F, Bernard B, Bain F, Byars D. Efficacy of ponazuril $15 \%$ oral paste as a treatment for equine protozoal myeloencephalitis. Vet Ther. 2001; 2:215-222. [PubMed: 19746664]

38. Gohil S, Herrmann S, Günther S, Cooke BM. Bovine babesiosis in the 21 st century: advances in biology and functional genomics. Int J Parasitol. 2013; 43:125-132. [PubMed: 23068911]

39. Gonzalez-Warleta M, Castro-Hermida JA, Regidor-Cerrillo J, Benavides J, Alvarez-Garcia G, Fuertes M, Ortega-Mora LM, Mezo M. Neospora caninum infection as a cause of reproductive failure in a sheep flock. Vet Res. 2014; 45:88. [PubMed: 25158756]

40. Grause JF, Ueti MW, Nelson JT, Knowles DP, Kappmeyer LS, Bunn TO. Efficacy of imidocarb dipropionate in eliminating Theileria equi from experimentally infected horses. Vet J. 2013; 196:541-546. [PubMed: 23199699]

41. Green JL, Moon RW, Whalley D, Bowyer PW, Wallace C, Rochani A, Nageshan RK, Howell SA, Grainger M, Jones HM, Ansell KH, Chapman TM, Taylor DL, Osborne SA, Baker DA, Tatu U, Holder AA. Imidazopyridazine Inhibitors of Plasmodium falciparum Calcium-Dependent Protein Kinase 1 Also Target Cyclic GMP-Dependent Protein Kinase and Heat Shock Protein 90 To Kill the Parasite at Different Stages of Intracellular Development. Antimicrob Agents Chemother. 2016; 60:1464-1475.

42. Hackstein JH, Mackenstedt U, Mehlhorn H, Meijerink JP, Schubert H, Leunissen JA. Parasitic apicomplexans harbor a chlorophyll a-D1 complex, the potential target for therapeutic triazines. Parasitol Res. 1995; 81:207-216. [PubMed: 7770426]

43. Harrell M, Carvounis PE. Current treatment of toxoplasma retinochoroiditis: an evidence-based review. J Ophthalmol. 2014; 2014:273506. [PubMed: 25197557]

44. Hemphill A, Aguado-Martínez A, Müller J. Approaches for the vaccination and treatment of Neospora caninum infections in mice and ruminant models. Parasitology. 2016; 143:245-259. [PubMed: 26626124]

45. Hines SA, Ramsay JD, Kappmeyer LS, Lau AO, Ojo KK, Van Voorhis WC, Knowles DP, Mealey $\mathrm{RH}$. Theileria equi isolates vary in susceptibility to imidocarb dipropionate but demonstrate uniform in vitro susceptibility to a bumped kinase inhibitor. Parasit Vectors. 2015; 8:33. [PubMed: 25600252]

46. Homer MJ, Aguilar-Delfin I, Telford SR, Krause PJ, Persing DH. Babesiosis. Clin Microbiol Rev. 2000; 13:451-469. [PubMed: 10885987]

47. Howe DK, MacKay RJ, Reed SM. Equine protozoal myeloencephalitis. Vet Clin North Am Equine Pract. 2014; 30:659-675. [PubMed: 25441115]

48. Huang W, Ojo KK, Zhang Z, Rivas K, Vidadala RS, Scheele S, DeRocher AE, Choi R, Hulverson MA, Barrett LK, Bruzual I, Siddaramaiah LK, Kerchner KM, Kurnick MD, Freiberg GM, Kempf D, Hol WG, Merritt EA, Neckermann G, de Hostos EL, Isoherranen N, Maly DJ, Parsons M, Doggett JS, Van Voorhis WC, Fan E. SAR Studies of 5-Aminopyrazole-4-carboxamide Analogues as Potent and Selective Inhibitors of Toxoplasma gondii CDPK1. ACS Med Chem Lett. 2015; 6:1184-1189. [PubMed: 26693272]

49. Imboden M, Schaefer DA, Bremel RD, Homan EJ, Riggs MW. Antibody fusions reduce onset of experimental Cryptosporidium parvum infection in calves. Vet Parasitol. 2012; 188:41-47. [PubMed: 22455725]

50. Johnson SM, Murphy RC, Geiger JA, DeRocher AE, Zhang Z, Ojo KK, Larson ET, Perera BG, Dale EJ, He P, Reid MC, Fox AM, Mueller NR, Merritt EA, Fan E, Parsons M, Van Voorhis WC, Maly DJ. Development of Toxoplasma gondii calcium-dependent protein kinase 1 (TgCDPK1) inhibitors with potent anti-toxoplasma activity. J Med Chem. 2012; 55:2416-2426. [PubMed: 22320388] 
51. Jongwutiwes S, Putaporntip C, Iwasaki T, Sata T, Kanbara H. Naturally acquired Plasmodium knowlesi malaria in human, Thailand. Emerg Infect Dis. 2004; 10:2211-2213. [PubMed: 15663864]

52. Katlama C, De Wit S, O'Doherty E, Van Glabeke M, Clumeck N. Pyrimethamine-clindamycin vs. pyrimethamine-sulfadiazine as acute and long-term therapy for toxoplasmic encephalitis in patients with AIDS. Clin Infect Dis. 1996; 22:268-275. [PubMed: 8838183]

53. Keyloun KR, Reid MC, Choi R, Song Y, Fox AM, Hillesland HK, Zhang Z, Vidadala R, Merritt EA, Lau AO, Maly DJ, Fan E, Barrett LK, VAN Voorhis WC, Ojo KK. The gatekeeper residue and beyond: homologous calcium-dependent protein kinases as drug development targets for veterinarian Apicomplexa parasites. Parasitology. 2014; 141:1499-1509. [PubMed: 24927073]

54. Khan A, Jordan C, Muccioli C, Vallochi AL, Rizzo LV, Belfort R Jr, Vitor RW, Silveira C, Sibley LD. Genetic divergence of Toxoplasma gondii strains associated with ocular toxoplasmosis, Brazil. Emerg Infect Dis. 2006; 12:942-949. [PubMed: 16707050]

55. Knapp KL, Rice NA. Human Coinfection with Borrelia burgdorferi and Babesia microti in the United States. J Parasitol Res. 2015; 2015:587131. [PubMed: 26697208]

56. Knowles DP. Control of Babesia equi parasitemia. Parasitol Today. 1996; 12:195-198. [PubMed: 15275213]

57. Kotloff KL, Nataro JP, Blackwelder WC, Nasrin D, Farag TH, Panchalingam S, Wu Y, Sow SO, Sur D, Breiman RF, Faruque AS, Zaidi AK, Saha D, Alonso PL, Tamboura B, Sanogo D, Onwuchekwa U, Manna B, Ramamurthy T, Kanungo S, Ochieng JB, Omore R, Oundo JO, Hossain A, Das SK, Ahmed S, Qureshi S, Quadri F, Adegbola RA, Antonio M, Hossain MJ, Akinsola A, Mandomando I, Nhampossa T, Acácio S, Biswas K, O'Reilly CE, Mintz ED, Berkeley LY, Muhsen K, Sommerfelt H, Robins-Browne RM, Levine MM. Burden and aetiology of diarrhoeal disease in infants and young children in developing countries (the Global Enteric Multicenter Study, GEMS): a prospective, case-control study. Lancet. 2013; 382:209-222. [PubMed: 23680352]

58. Kumar S, Gupta AK, Pal Y, Dwivedi SK. In-vivo therapeutic efficacy trial with artemisinin derivative, buparvaquone and imidocarb dipropionate against Babesia equi infection in donkeys. $\mathrm{J}$ Vet Med Sci. 2003; 65:1171-1177. [PubMed: 14665744]

59. Kumar S, Kumar R, Sugimoto C. A perspective on Theileria equi infections in donkeys. Jpn J Vet Res. 2009; 56:171-180. [PubMed: 19358444]

60. Kuttler KL, Zaugg JL, Gipson CA. Imidocarb and parvaquone in the treatment of piroplasmosis (Babesia equi) in equids. Am J Vet Res. 1987; 48:1613-1616. [PubMed: 3434908]

61. Lapointe JM, Duignan PJ, Marsh AE, Gulland FM, Barr BC, Naydan DK, King DP, Farman CA, Huntingdon KA, Lowenstine LJ. Meningoencephalitis due to a Sarcocystis neurona-like protozoan in Pacific harbor seals (Phoca vitulina richardsi). J Parasitol. 1998; 84:1184-1189. [PubMed: 9920311]

62. Larson ET, Ojo KK, Murphy RC, Johnson SM, Zhang Z, Kim JE, Leibly DJ, Fox AM, Reid MC, Dale EJ, Perera BG, Kim J, Hewitt SN, Hol WG, Verlinde CL, Fan E, Van Voorhis WC, Maly DJ, Merritt EA. Multiple determinants for selective inhibition of apicomplexan calcium-dependent protein kinase CDPK1. J Med Chem. 2012; 55:2803-2810. [PubMed: 22369268]

63. Lindsay DS, Thomas NJ, Rosypal AC, Dubey JP. Dual Sarcocystis neurona and Toxoplasma gondii infection in a Northern sea otter from Washington state, USA. Vet Parasitol. 2001; 97:319-327. [PubMed: 11390085]

64. Liu Y, Bishop A, Witucki L, Kraybill B, Shimizu E, Tsien J, Ubersax J, Blethrow J, Morgan DO, Shokat KM. Structural basis for selective inhibition of Src family kinases by PP1. Chem Biol. 1999; 6:671-678. [PubMed: 10467133]

65. Lourido S, Shuman J, Zhang C, Shokat KM, Hui R, Sibley LD. Calcium-dependent protein kinase 1 is an essential regulator of exocytosis in Toxoplasma. Nature. 2010; 465:359-362. [PubMed: 20485436]

66. Lourido S, Tang K, Sibley LD. Distinct signalling pathways control Toxoplasma egress and hostcell invasion. EMBO J. 2012; 31:4524-4534. [PubMed: 23149386] 
67. Lourido S, Zhang C, Lopez MS, Tang K, Barks J, Wang Q, Wildman SA, Shokat KM, Sibley LD. Optimizing small molecule inhibitors of calcium-dependent protein kinase 1 to prevent infection by Toxoplasma gondii. J Med Chem. 2013; 56:3068-3077. [PubMed: 23470217]

68. Mackay RJ, Tanhauser ST, Gillis KD, Mayhew IG, Kennedy TJ. Effect of intermittent oral administration of ponazuril on experimental Sarcocystis neurona infection of horses. Am J Vet Res. 2008; 69:396-402. [PubMed: 18312139]

69. Martino R, Bretagne S, Einsele H, Maertens J, Ullmann AJ, Parody R, Schumacher U, Pautas C, Theunissen K, Schindel C, Munoz C, Margall N, Cordonnier C, Marrow T. Infectious Disease Working Party of the European Group for B. Early detection of Toxoplasma infection by molecular monitoring of Toxoplasma gondii in peripheral blood samples after allogeneic stem cell transplantation. Clin Infect Dis. 2005; 40:67-78. [PubMed: 15614694]

70. McLeod R, Boyer K, Karrison T, Kasza K, Swisher C, Roizen N, Jalbrzikowski J, Remington J, Heydemann P, Noble AG, Mets M, Holfels E, Withers S, Latkany P, Meier P. Toxoplasmosis Study G. Outcome of treatment for congenital toxoplasmosis, 1981-2004: the National Collaborative Chicago-Based, Congenital Toxoplasmosis Study. Clin Infect Dis. 2006; 42:1383-1394. [PubMed: 16619149]

71. Meyer C, Guthrie AJ, Stevens KB. Clinical and clinicopathological changes in 6 healthy ponies following intramuscular administration of multiple doses of imidocarb dipropionate. J S Afr Vet Assoc. 2005; 76:26-32. [PubMed: 15900897]

72. Miller MA, Conrad PA, Harris M, Hatfield B, Langlois G, Jessup DA, Magargal SL, Packham AE, Toy-Choutka S, Melli AC, Murray MA, Gulland FM, Grigg ME. A protozoal-associated epizootic impacting marine wildlife: mass-mortality of southern sea otters (Enhydra lutris nereis) due to Sarcocystis neurona infection. Vet Parasitol. 2010; 172:183-194. [PubMed: 20615616]

73. Moine E, Denevault-Sabourin C, Debierre-Grockiego F, Silpa L, Gorgette O, Barale JC, Jacquiet P, Brossier F, Gueiffier A, Dimier-Poisson I, Enguehard-Gueiffier C. A small-molecule cell-based screen led to the identification of biphenylimidazoazines with highly potent and broad-spectrum anti-apicomplexan activity. Eur J Med Chem. 2015; 89:386-400. [PubMed: 25462254]

74. Moine E, Dimier-Poisson I, Enguehard-Gueiffier C, Loge C, Penichon M, Moire N, Delehouze C, Foll-Josselin B, Ruchaud S, Bach S, Gueiffier A, Debierre-Grockiego F, Denevault-Sabourin C. Development of new highly potent imidazo[1,2-b]pyridazines targeting Toxoplasma gondii calcium-dependent protein kinase 1. Eur J Med Chem. 2015; 105:80-105. [PubMed: 26479029]

75. Monney T, Hemphill A. Vaccines against neosporosis: what can we learn from the past studies? Exp Parasitol. 2014; 140:52-70. [PubMed: 24602874]

76. Moreno B, Collantes-Fernandez E, Villa A, Navarro A, Regidor-Cerrillo J, Ortega-Mora LM. Occurrence of Neospora caninum and Toxoplasma gondii infections in ovine and caprine abortions. Vet Parasitol. 2012; 187:312-318. [PubMed: 22260901]

77. Murphy RC, Ojo KK, Larson ET, Castellanos-Gonzalez A, Perera BG, Keyloun KR, Kim JE, Bhandari JG, Muller NR, Verlinde CL, White AC Jr, Merritt EA, Van Voorhis WC, Maly DJ. Discovery of Potent and Selective Inhibitors of Calcium-Dependent Protein Kinase 1 (CDPK1) from C. parvum and T. gondii. ACS Med Chem Lett. 2010; 1:331-335. [PubMed: 21116453]

78. Nagamune K, Sibley LD. Comparative genomic and phylogenetic analyses of calcium ATPases and calcium-regulated proteins in the apicomplexa. Mol Biol Evol. 2006; 23:1613-1627. [PubMed: 16751258]

79. Ojo KK, Dangoudoubiyam S, Verma SK, Scheele S, DeRocher AE, Yeargan M, Choi R, Smith RR, Rivas KL, Hulverson MA, Barrett LK, Fan E, Maly DJ, Parsons M, Dubey JP, Howe DK, Van Voorhis WC. Selective Inhibition of Sarcocystis neurona Calcium-Dependent Protein Kinase 1 for Equine Protozoal Myeloencephalitis Therapy. International Journal for Parasitology. 2016 in press.

80. Ojo KK, Eastman RT, Vidadala R, Zhang Z, Rivas KL, Choi R, Lutz JD, Reid MC, Fox AM, Hulverson MA, Kennedy M, Isoherranen N, Kim LM, Comess KM, Kempf DJ, Verlinde CL, Su XZ, Kappe SH, Maly DJ, Fan E, Van Voorhis WC. A Specific Inhibitor of PfCDPK4 Blocks Malaria Transmission: Chemical-genetic Validation. J Infect Dis. 2014; 209:275-284. [PubMed: 24123773]

81. Ojo KK, Larson ET, Keyloun KR, Castaneda LJ, Derocher AE, Inampudi KK, Kim JE, Arakaki TL, Murphy RC, Zhang L, Napuli AJ, Maly DJ, Verlinde CL, Buckner FS, Parsons M, Hol WG, 
Merritt EA, Van Voorhis WC. Toxoplasma gondii calcium-dependent protein kinase 1 is a target for selective kinase inhibitors. Nat Struct Mol Biol. 2010; 17:602-607. [PubMed: 20436472]

82. Ojo KK, Pfander C, Mueller NR, Burstroem C, Larson ET, Bryan CM, Fox AM, Reid MC, Johnson SM, Murphy RC, Kennedy M, Mann H, Leibly DJ, Hewitt SN, Verlinde CL, Kappe S, Merritt EA, Maly DJ, Billker O, Van Voorhis WC. Transmission of malaria to mosquitoes blocked by bumped kinase inhibitors. J Clin Invest. 2012; 122:2301-2305. [PubMed: 22565309]

83. Ojo KK, Reid MC, Kallur Siddaramaiah L, Muller J, Winzer P, Zhang Z, Keyloun KR, Vidadala RS, Merritt EA, Hol WG, Maly DJ, Fan E, Van Voorhis WC, Hemphill A. Neospora caninum calcium-dependent protein kinase 1 is an effective drug target for neosporosis therapy. PLoS One. 2014; 9:e92929. [PubMed: 24681759]

84. Pantenburg B, Cabada MM, White AC Jr. Treatment of cryptosporidiosis. Expert Rev Anti Infect Ther. 2009; 7:385-391. [PubMed: 19400754]

85. Pedersen PJ, Thomsen KB, Olander ER, Hauser F, Tejada MeL, Poulsen KL, Grubb S, Buhl R, Calloe K, Klaerke DA. Molecular Cloning and Functional Expression of the Equine K+ Channel KV11.1 (Ether à Go-Go-Related/KCNH2 Gene) and the Regulatory Subunit KCNE2 from Equine Myocardium. PLoS One. 2015; 10:e0138320. [PubMed: 26376488]

86. Pedroni MJ, Vidadala RS, Choi R, Keyloun KR, Reid MC, Murphy RC, Barrett LK, Van Voorhis WC, Maly DJ, Ojo KK, Lau AO. Bumped kinase inhibitor prohibits egression in Babesia bovis. Vet Parasitol. 2016; 215:22-28. [PubMed: 26790733]

87. Porter SB, Sande MA. Toxoplasmosis of the central nervous system in the acquired immunodeficiency syndrome. N Engl J Med. 1992; 327:1643-1648. [PubMed: 1359410]

88. Rabaud C, May T, Amiel C, Katlama C, Leport C, Ambroise-Thomas P, Canton P. Extracerebral toxoplasmosis in patients infected with HIV. A French National Survey. Medicine (Baltimore). 1994; 73:306-314. [PubMed: 7984082]

89. Reed SM, Furr M, Howe DK, Johnson AL, MacKay RJ, Morrow JK, Pusterla N, Witonsky S. Equine Protozoal Myeloencephalitis: An Updated Consensus Statement with a Focus on Parasite Biology, Diagnosis, Treatment, and Prevention. J Vet Intern Med. 2016; 30:491-502. [PubMed: 26857902]

90. Reichel MP, Alejandra Ayanegui-Alcérreca M, Gondim LF, Ellis JT. What is the global economic impact of Neospora caninum in cattle - the billion dollar question. Int J Parasitol. 2013; 43:133142. [PubMed: 23246675]

91. Rosonke BJ, Brown SR, Tornquist SJ, Snyder SP, Garner MM, Blythe LL. Encephalomyelitis associated with a Sarcocystis neurona-like organism in a sea otter. J Am Vet Med Assoc. 1999; 215:1839-1842. 1807. [PubMed: 10613219]

92. Schaefer DA, Auerbach-Dixon BA, Riggs MW. Characterization and formulation of multiple epitope-specific neutralizing monoclonal antibodies for passive immunization against cryptosporidiosis. Infect Immun. 2000; 68:2608-2616. [PubMed: 10768951]

93. Schaefer DA, Betzer DP, Smith KD, Millman ZG, Michalski HC, Menchaca SE, Zambriski JA, Ojo KK, Hulverson MA, Arnold SL, Rivas KL, Vidadala RS, Huang W, Barrett LK, Maly DJ, Fan E, Van Voorhis WC, Riggs MW. Novel Bumped Kinase Inhibitors Are Safe and Effective Therapeutics in the Calf Clinical Model for Cryptosporidiosis. J Infect Dis. 2016; 214:1856-1864. [PubMed: 27923949]

94. Schneider P, Bousema T, Omar S, Gouagna L, Sawa P, Schallig H, Sauerwein R. (Sub)microscopic Plasmodium falciparum gametocytaemia in Kenyan children after treatment with sulphadoxinepyrimethamine monotherapy or in combination with artesunate. Int J Parasitol. 2006; 36:403-408. [PubMed: 16500657]

95. Scoles GA, Hutcheson HJ, Schlater JL, Hennager SG, Pelzel AM, Knowles DP. Equine piroplasmosis associated with Amblyomma cajennense Ticks, Texas, USA. Emerg Infect Dis. 2011; 17:1903-1905. [PubMed: 22000367]

96. Short MA, Clark CK, Harvey JW, Wenzlow N, Hawkins IK, Allred DR, Knowles DP, Corn JL, Grause JF, Hennager SG, Kitchen DL, Traub-Dargatz JL. Outbreak of equine piroplasmosis in Florida. J Am Vet Med Assoc. 2012; 240:588-595. [PubMed: 22332629] 
97. Sugi T, Kawazu S, Horimoto T, Kato K. A single mutation in the gatekeeper residue in TgMAPKL-1 restores the inhibitory effect of a bumped kinase inhibitor on the cell cycle. Int $\mathbf{J}$ Parasitol Drugs Drug Resist. 2015; 5:1-8. [PubMed: 25941623]

98. Taylor SM, Kenny J, Mallon T. The effect of multiple rapid passage on strains of Babesia divergens: a comparison of the clinical effects on juvenile and adult cattle of passaged and irradiated parasites. J Comp Pathol. 1983; 93:391-396. [PubMed: 6886085]

99. Tecles F, Cerón JJ. Determination of whole blood cholinesterase in different animal species using specific substrates. Res Vet Sci. 2001; 70:233-238. [PubMed: 11676619]

100. Tenter AM, Heckeroth AR, Weiss LM. Toxoplasma gondii: from animals to humans. Int J Parasitol. 2000; 30:1217-1258. [PubMed: 11113252]

101. Tran TM, Li S, Doumbo S, Doumtabe D, Huang CY, Dia S, Bathily A, Sangala J, Kone Y, Traore A, Niangaly M, Dara C, Kayentao K, Ongoiba A, Doumbo OK, Traore B, Crompton PD. An intensive longitudinal cohort study of Malian children and adults reveals no evidence of acquired immunity to Plasmodium falciparum infection. Clin Infect Dis. 2013; 57:40-47. [PubMed: 23487390]

102. Ueti MW, Mealey RH, Kappmeyer LS, White SN, Kumpula-McWhirter N, Pelzel AM, Grause JF, Bunn TO, Schwartz A, Traub-Dargatz JL, Hendrickson A, Espy B, Guthrie AJ, Fowler WK, Knowles DP. Re-emergence of the apicomplexan Theileria equi in the United States: elimination of persistent infection and transmission risk. PLoS One. 2012; 7:e44713. [PubMed: 22970295]

103. United States. Animal and Plant Health Inspection Service. Equine piroplasmosis, APHIS factsheet. U.S. Dept. of Agriculture, Animal and Plant Health Inspection Service; Riverdale, Md: 2008. p. 2 unnumbered pages

104. Vannier EG, Diuk-Wasser MA, Ben Mamoun C, Krause PJ. Babesiosis. Infect Dis Clin North Am. 2015; 29:357-370. [PubMed: 25999229]

105. Vidadala RS, Ojo KK, Johnson SM, Zhang Z, Leonard SE, Mitra A, Choi R, Reid MC, Keyloun KR, Fox AM, Kennedy M, Silver-Brace T, Hume JC, Kappe S, Verlinde CL, Fan E, Merritt EA, Van Voorhis WC, Maly DJ. Development of potent and selective Plasmodium falciparum calcium-dependent protein kinase 4 (PfCDPK4) inhibitors that block the transmission of malaria to mosquitoes. Eur J Med Chem. 2014; 74:562-573. [PubMed: 24531197]

106. Vidadala RS, Rivas KL, Ojo KK, Hulverson MA, Zambriski JA, Bruzual I, Schultz TL, Huang W, Zhang Z, Scheele S, DeRocher AE, Choi R, Barrett LK, Siddaramaiah LK, Hol WG, Fan E, Merritt EA, Parsons M, Freiberg G, Marsh K, Kempf DJ, Carruthers VB, Isoherranen N, Doggett JS, Van Voorhis WC, Maly DJ. Development of an Orally Available and Central Nervous System (CNS) Penetrant Toxoplasma gondii Calcium-Dependent Protein Kinase 1 (TgCDPK1) Inhibitor with Minimal Human Ether-a-go-go-Related Gene (hERG) Activity for the Treatment of Toxoplasmosis. J Med Chem. 2016; 59:6531-6546. [PubMed: 27309760]

107. Wellems TE, Hayton K, Fairhurst RM. The impact of malaria parasitism: from corpuscles to communities. J Clin Invest. 2009; 119:2496-2505. [PubMed: 19729847]

108. Wernimont AK, Artz JD, Finerty P, Lin YH, Amani M, Allali-Hassani A, Senisterra G, Vedadi M, Tempel W, Mackenzie F, Chau I, Lourido S, Sibley LD, Hui R. Structures of apicomplexan calcium-dependent protein kinases reveal mechanism of activation by calcium. Nat Struct Mol Biol. 2010; 17:596-601. [PubMed: 20436473]

109. Wilairatana P, Krudsood S, Tangpukdee N. Appropriate time for primaquine treatment to reduce Plasmodium falciparum transmission in hypoendemic areas. Korean J Parasitol. 2010; 48:179_ 182. [PubMed: 20585538]

110. Winzer P, Muller J, Aguado-Martinez A, Rahman M, Balmer V, Manser V, Ortega-Mora LM, Ojo KK, Fan E, Maly DJ, Van Voorhis WC, Hemphill A. In Vitro and In Vivo Effects of the Bumped Kinase Inhibitor 1294 in the Related Cyst-Forming Apicomplexans Toxoplasma gondii and Neospora caninum. Antimicrob Agents Chemother. 2015; 59:6361-6374. [PubMed: 26248379]

111. World Health Organization. World Malaria Report 2014. World Health Organization; Geneva, Switzerland: 2014.

112. Zhang C, Kenski DM, Paulson JL, Bonshtien A, Sessa G, Cross JV, Templeton DJ, Shokat KM. A second-site suppressor strategy for chemical genetic analysis of diverse protein kinases. Nat Methods. 2005; 2:435-441. [PubMed: 15908922] 
113. Zhang Z, Ojo KK, Johnson SM, Larson ET, He P, Geiger JA, Castellanos-Gonzalez A, White AC, Parsons M, Merritt EA, Maly DJ, Verlinde CL, Van Voorhis WC, Fan E. Benzoylbenzimidazolebased selective inhibitors targeting Cryptosporidium parvum and Toxoplasma gondii calciumdependent protein kinase-1. Bioorg Med Chem Lett. 2012; 22:5264-5267. [PubMed: 22795629]

114. Zhang Z, Ojo KK, Vidadala R, Huang W, Geiger JA, Scheele S, Choi R, Reid MC, Keyloun KR, Rivas K, Siddaramaiah LK, Comess KM, Robinson KP, Merta PJ, Kifle L, Hol WG, Parsons M, Merritt EA, Maly DJ, Verlinde CL, Van Voorhis WC, Fan E. Potent and selective inhibitors of CDPK1 from T. gondii and C. parvum based on a 5-aminopyrazole-4-carboxamide scaffold. ACS Med Chem Lett. 2014; 5:40-44. [PubMed: 24494061]

115. Zuccotto F, Ardini E, Casale E, Angiolini M. Through the "gatekeeper door": exploiting the active kinase conformation. J Med Chem. 2010; 53:2681-2694. [PubMed: 20000735] 


\section{Highlights}

- $\quad$ Many apicomplexan calcium dependent protein kinases (CDPKs) are validated drug targets

- $\quad$ These CDPKs have atypically small gatekeeper residues and are inhibited by bumped kinase inhibitors (BKIs)

- Highly selective ATP-competitive BKIs inhibit growth of many apicomplexan parasites at concentrations non-toxic to mammalian cells and some have demonstrated proof-of- concept therapy in animal infection models

- $\quad$ BKIs have potential as therapeutics for diseases caused by apicomplexan pathogens 


\section{(a)}<smiles>[R]c1nn([R2])c2ncnc(N)c12</smiles>

\section{The original BKI scaffold: pyrazolopyrimidine (PP)}<smiles>[R7]c1nn([R2])c(N)c1C(N)=O</smiles>

\section{An alternative 5-aminopyrazole- 4-carboxamide (AC) scaffold}

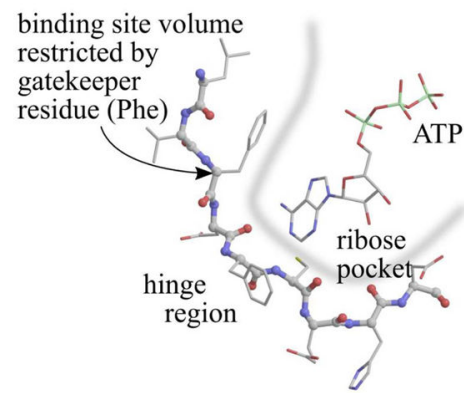

(b)

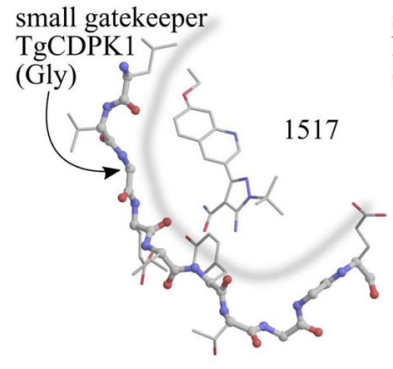

(c)

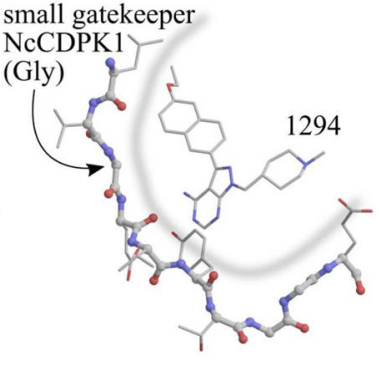

(d)

Fig. 1. BKIs core scaffold and orientation with enzymes ATP binding sites (a) Pyrazolopyrimidines (PP) and alternative 5-aminopyrazole-4-carboxamide (AC) scaffold chemical backbone for CDPK inhibitors. (b) Typical protein kinase active site. The volume accessible for ATP binding, indicated by the thick blue line, is limited by the presence of a large gatekeeper residue, in this case phenylalanine 103 of human CDK9. (c) Active site of T. gondii CDPK1 with AC scaffold BKI-1517. The large R1 substituent occupies a hydrophobic region made accessible by the absence of sidechain atoms in the glycine gatekeeper residue. (d) Active site of $N$. caninum CDPK1 with PP scaffold BKI-1294. In 
addition to the large $\mathrm{R} 1$ group, this inhibitor contains a large $\mathrm{R} 2$ group that extends deeper into the ribose pocket. The three crystal structures shown are 3BLQ, 4ONA, and 4MX9. 
<smiles>[R]c1ccc2nc([R])c([R3])n2n1</smiles>

Imidazopyridazines<smiles>[R2]Nc1nc2ccc(C(=O)c3ccccc3)cc2n1[R1]</smiles>

Benzoylbenzimidazoles

Fig. 2. Imidazopyridazines and benzoylbenzimidazoles are two other chemical scaffolds previously used as backbone for development of BKIs to target apicomplexan parasite enzymes. 


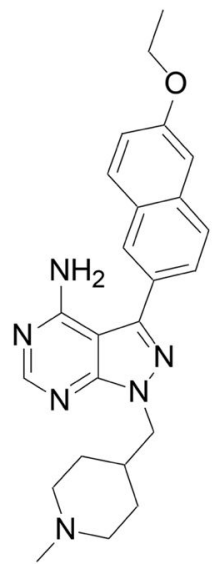

1294

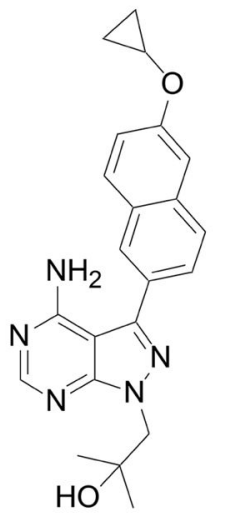

1553

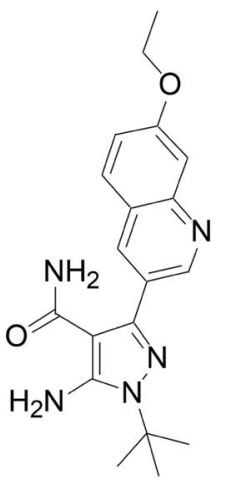

1517

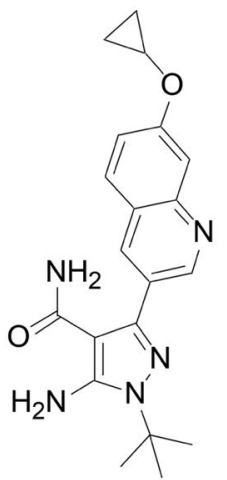

1586

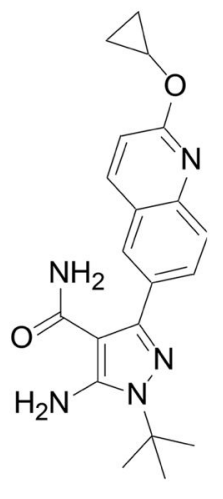

1643

Fig. 3. Chemical structures

Chemical structures of lead bumped kinase inhibitors with demonstrated activities against apicomplexan calcium-dependent protein kinase enzymes and parasites growth and proliferation.

Exp Parasitol. Author manuscript; available in PMC 2018 September 01. 

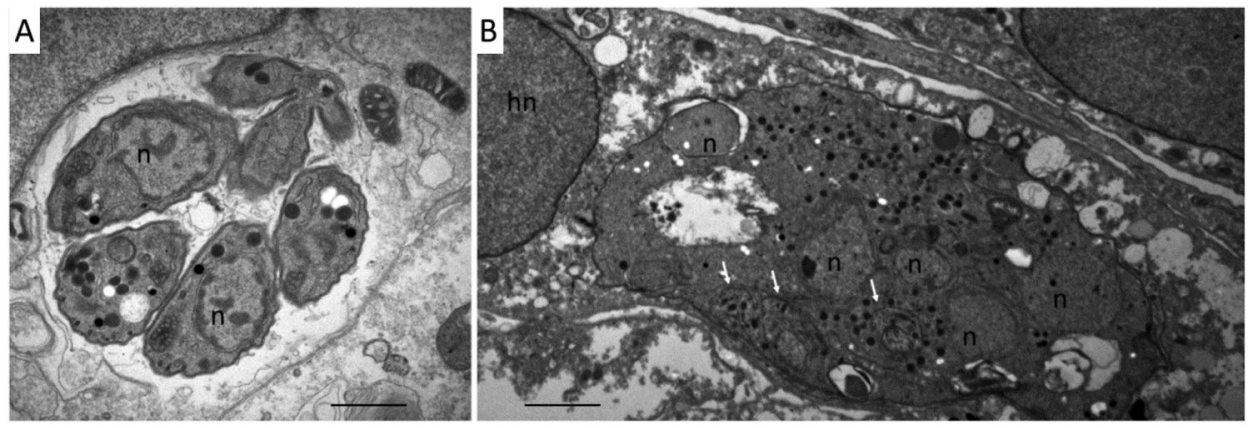

Fig. 4. BKI-1294 induces the formation of multinucleated parasite complexes in N.caninum infected cells

A: TEM showing a parasitophorous vacuole containing numerous $N$. caninum tachyzoites cultured in the absence of BKI-1294. B. N. caninum tachyzoites were allowed to invade the

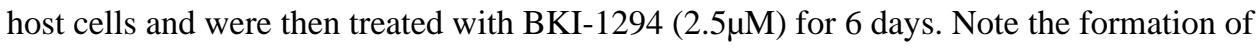
multinucleated parasites, still enclosed within a vacuole. $\mathrm{n}=$ parasite nucleus; $\mathrm{hn}=$ host cell nucleus. Bars $=1 \mu \mathrm{m}$ 


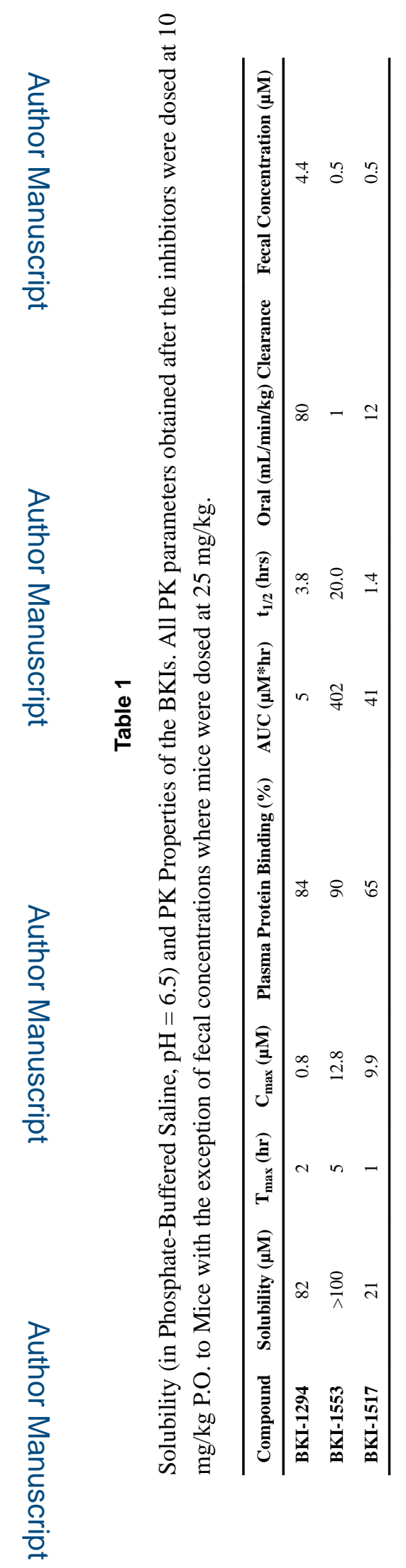

Exp Parasitol. Author manuscript; available in PMC 2018 September 01. 

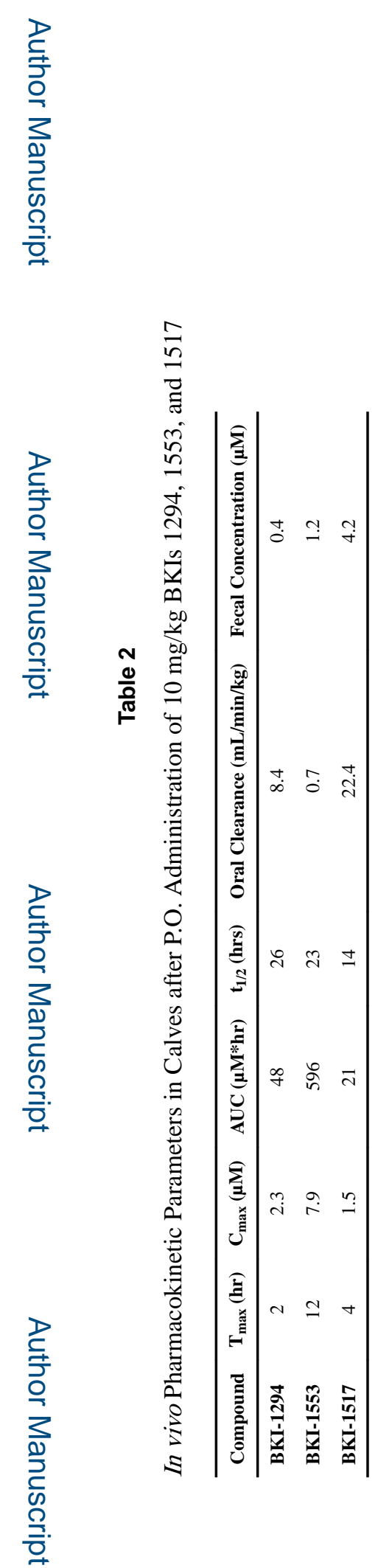

Exp Parasitol. Author manuscript; available in PMC 2018 September 01. 


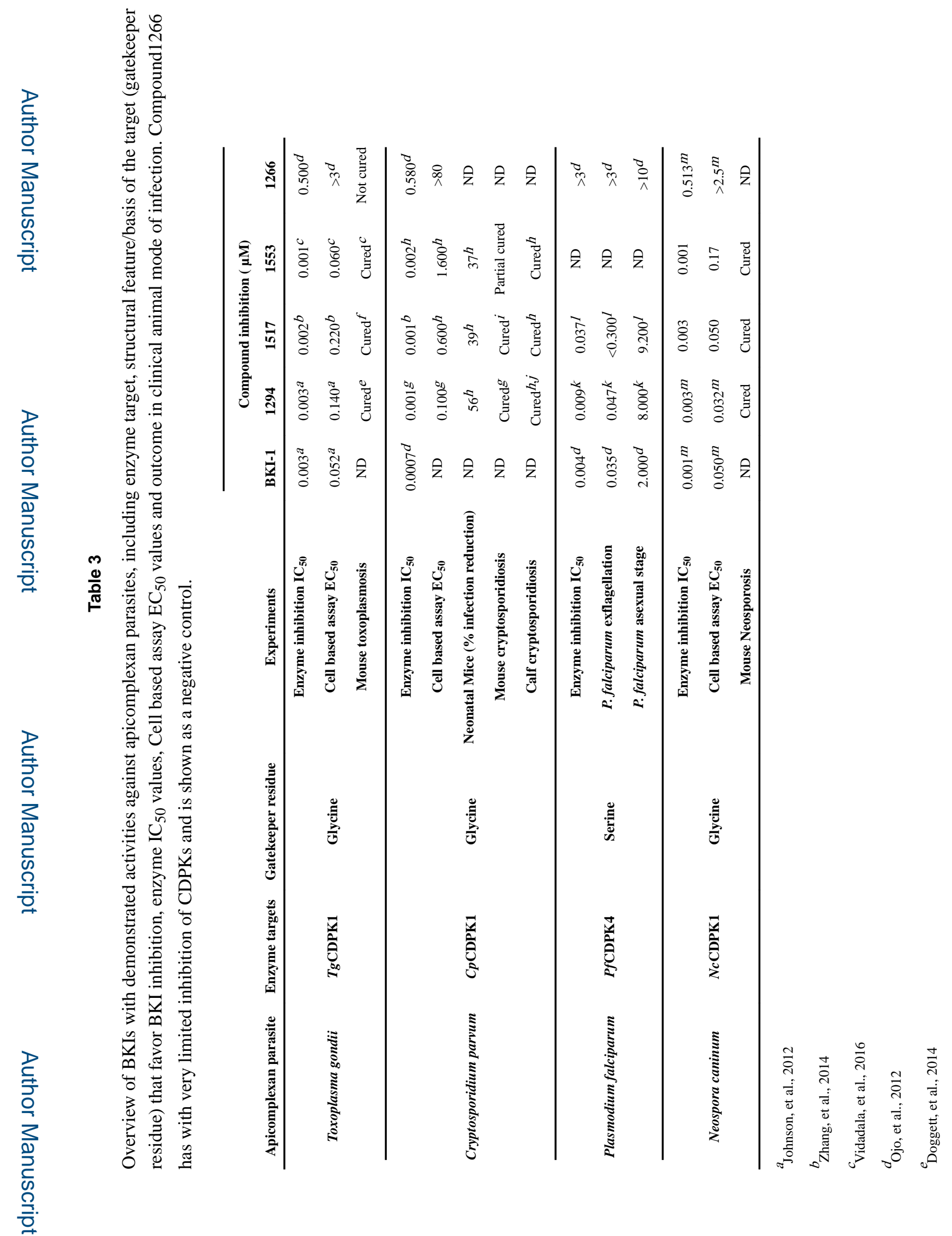

Exp Parasitol. Author manuscript; available in PMC 2018 September 01. 

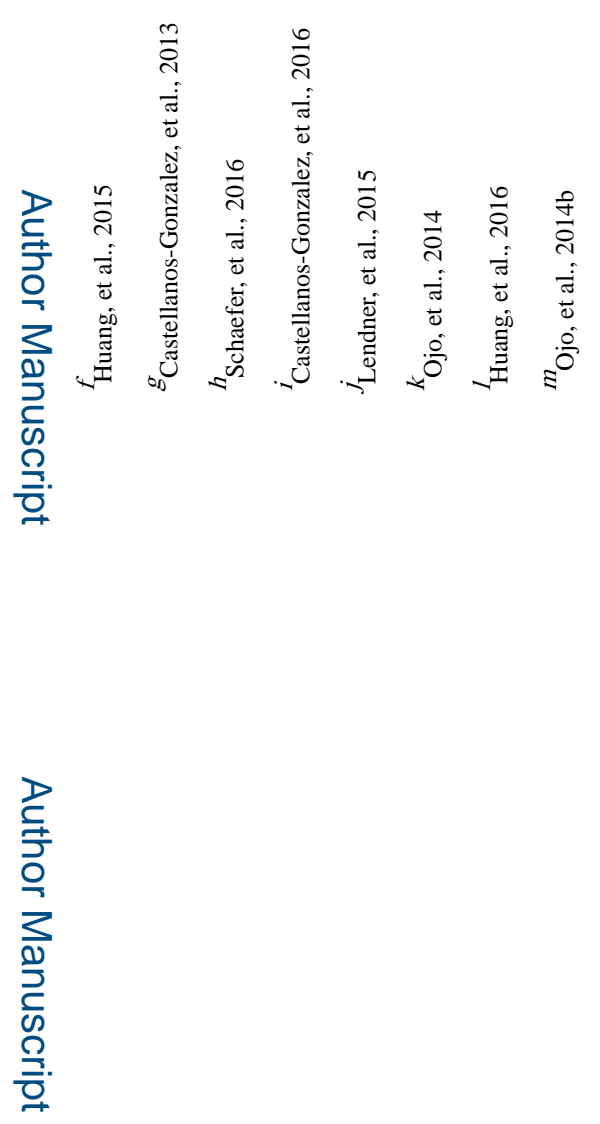

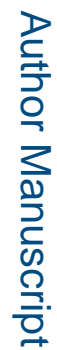

롤

Exp Parasitol. Author manuscript; available in PMC 2018 September 01. 